\title{
Air quality simulations of wildfires in the Pacific Northwest evaluated with surface and satellite observations during the summers of 2007 and 2008
}

\author{
F. L. Herron-Thorpe ${ }^{1}$, G. H. Mount ${ }^{1}$, L. K. Emmons ${ }^{2}$, B. K. Lamb ${ }^{1}$, D. A. Jaffe ${ }^{3,4}$, N. L. Wigder ${ }^{3,4}$, S. H. Chung ${ }^{1}$, \\ R. Zhang ${ }^{1}$, M. D. Woelfle ${ }^{3}$, and J. K. Vaughan ${ }^{1}$ \\ ${ }^{1}$ Laboratory for Atmospheric Research; Washington State University, Pullman, WA, USA \\ ${ }^{2}$ National Center for Atmospheric Research, Boulder, CO, USA \\ ${ }^{3}$ Department of Atmospheric Sciences; University of Washington, Seattle, WA, USA \\ ${ }^{4}$ School of Science, Technology, Engineering and Mathematics, University of Washington-Bothell, \\ Bothell, WA, USA
}

Correspondence to: F. L. Herron-Thorpe (farrenthorpe@wsu.edu)

Received: 26 February 2014 - Published in Atmos. Chem. Phys. Discuss.: 6 May 2014

Revised: 17 September 2014 - Accepted: 6 October 2014 - Published: 27 November 2014

\begin{abstract}
Evaluation of a regional air quality forecasting system for the Pacific Northwest was carried out using a suite of surface and satellite observations. Wildfire events for the 2007 and 2008 fire seasons were simulated using the Air Information Report for Public Access and Community Tracking v.3 (AIRPACT-3) framework utilizing the Community Multi-scale Air Quality (CMAQ) model. Fire emissions were simulated using the BlueSky framework with fire locations determined by the Satellite Mapping Automated Reanalysis Tool for Fire Incident Reconciliation (SMARTFIRE). Plume rise was simulated using two different methods: the Fire Emission Production Simulator (FEPS) and the Sparse Matrix Operator Kernel Emissions (SMOKE) model. Predicted plume top heights were compared to the CloudAerosol LIDAR with Orthogonal Polarization (CALIOP) instrument aboard the Cloud Aerosol LIDAR and Infrared Pathfinder Satellite Observation (CALIPSO) satellite. Carbon monoxide predictions were compared to the Atmospheric InfraRed Sounder (AIRS) instrument aboard the Aqua satellite. Horizontal distributions of column aerosol optical depth (AOD) were compared to retrievals by the Moderate Resolution Imaging Spectroradiometer (MODIS) instrument aboard the Aqua satellite. Model tropospheric nitrogen dioxide distributions were compared to retrievals from the Ozone Monitoring Instrument (OMI) aboard the Aura satellite. Surface ozone and $\mathrm{PM}_{2.5}$ predictions were compared to surface observations. The AIRPACT-3 model
\end{abstract}

captured the location and transport direction of fire events well, but sometimes missed the timing of fire events and overall underestimated the $\mathrm{PM}_{2.5}$ impact of wildfire events at surface monitor locations. During the 2007 (2008) fire period, the fractional biases (FBs) of AIRPACT-3 for various pollutant observations included: average $24 \mathrm{~h} \mathrm{PM}_{2.5}$ $\mathrm{FB}=-33 \%(-27 \%)$; maximum daily average $8 \mathrm{~h}$ ozone $\mathrm{FB}=-8 \%(+1 \%)$; $\mathrm{AOD} \mathrm{FB}=-61 \%(-53 \%)$; total column $\mathrm{CO} F \mathrm{FB}=-10 \%(-5 \%)$; and tropospheric column $\mathrm{NO}_{2}$ $\mathrm{FB}=-39 \%(-28 \%)$. The bias in total column $\mathrm{CO}$ is within the range of expected error. Fractional biases of AIRPACT3 plume tops were found to be $-46 \%$ when compared in terms of above mean sea level, but only $-28 \%$ when compared in terms of above ground level, partly due to the underestimation of AIRPACT-3 ground height in complex terrain that results from the $12 \mathrm{~km}$ grid-cell smoothing. We conclude that aerosol predictions were too low for locations greater than $\sim 100-300 \mathrm{~km}$ downwind from wildfire sources and that model predictions are likely under-predicting secondary organic aerosol (SOA) production, due to a combination of very low volatile organic compound (VOC) emission factors used in the United States Forest Service Consume model, an incomplete speciation of VOC to SOA precursors in SMOKE, and under-prediction by the SOA parameterization within CMAQ. 


\section{Introduction}

The Pacific Northwest is home to a rural landscape that periodically experience large wildfires, especially during dry summers. Wildfire smoke and other particulate matter (PM) emitted into the atmosphere can cause severe health problems. Informing the public about upcoming poor air quality expected from fires requires a comprehensive knowledge of fire locations, land type being burned, terrain, wind direction, available moisture, timing, and other conditions. Reports generated by fire fighters are quickly provided to air quality managers by the United States Forest Service, but it is difficult to get an accurate assessment of wildfire conditions in remote locations with rough terrain, few access roads, and sparse air quality monitor distribution. Meteorological forecasts and chemistry transport models can be used to predict the air quality impacts of wildfire emissions, but the task is challenging (Simon et al., 2012). Satellite retrievals of air quality indicators provide a valuable asset that, when combined with surface measurements, can help to assess the validity of air quality models simulating large wildfire events. The analysis presented here utilizes multiple satellite products to evaluate simulations from the Air Information Report for Public Access and Community Tracking v.3 (AIRPACT3) regional air quality model, which utilizes the BlueSky fire emissions framework and the Community Multi-scale Air Quality (CMAQ) model. As such, this work demonstrates how a suite of satellite products can be combined with in situ observations to inform improvement of air quality forecast performance.

The objective of this work is to report the level of performance and types of error that were found for modeled fire locations, plume heights, and pollutant concentrations simulated in AIRPACT-3, based on a combination of satellite products and surface pollutant observations. It is essential that future AIRPACT versions accurately predict the impact of fires, given the very large fire seasons in recent history (e.g., 2012) and the expected increase of fire activity as the regional climate changes. We chose to use finalized activity reports to derive wildfire emissions, rather than forecastmode data, so that we could focus on the emissions from known fire events and test the model's performance in a "best-case" scenario. We modeled wildfire events that occurred during the summers of 2007 and 2008 because of their interest to AIRPACT users, the extensive fire activity that occurred, and because satellite coverage throughout NASA's Afternoon Train (A-Train) of satellites was relatively complete. We focused on A-Train satellite data to keep overpass times consistent ( $\sim$ 01:45 PST) and because fire activity is best detected in the afternoon, when wildfires are most active. Simulations of the historically large fires that ignited in Idaho, Nevada, and Montana throughout July 2007 provided great insight into AIRPACT-3 wildfire performance. In addition, the Northern California fires that ignited on 21 June 2008 provided further valuable model information due to the

\section{FCCS Fuels and Modeled Fires}
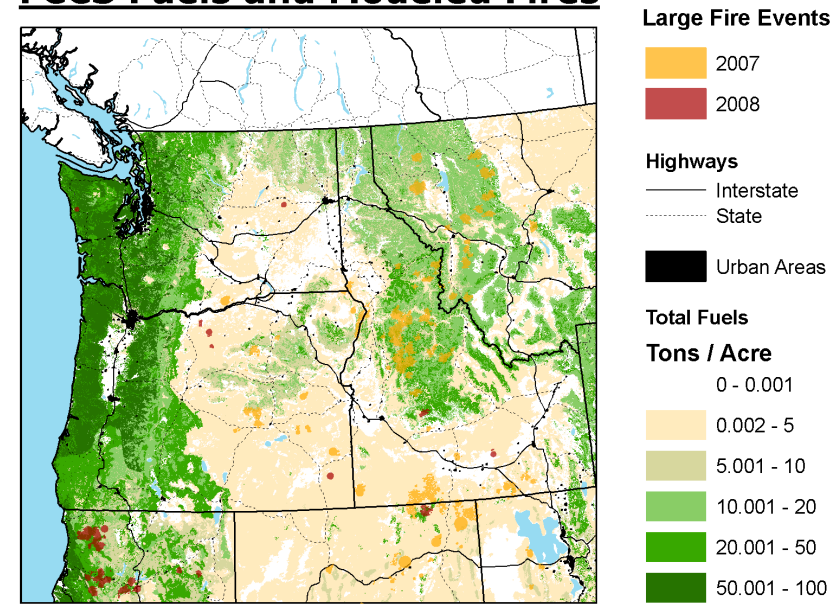

Figure 1. Fire events with individual burn areas greater than 5000 acres during the analysis periods of 2007 (orange) and 2008 (red). Total fuel loading derived from the FCCS v1 is also shown for the AIRPACT-3 domain.

technical challenge posed by the large fires that occurred on both sides of the southern boundary of the modeling domain.

The western US experienced abnormally dry winter and spring seasons in 2007, which led to a summer drought and extensive wildfire events in Idaho, Nevada, and Montana. Extreme temperatures and sparse precipitation during early summer 2007, coupled with lightning activity and several strong wind events, led to several expanding, long-lived fires. Precipitation events that started on 17 August slowed the expansion of wildfires and allowed fire fighters to contain many of the burning areas, though some fires continued to burn into September. The National Interagency Coordination Center (NICC) at the National Interagency Fire Center (NIFC; http://www.predictiveservices.nifc.gov/) reported that over 800000 acres burned in Nevada during July 2007. By 31 August the Great Basin and Northern Rockies had wildfires that burned over 4 million acres, nearly twice the typical year-to-date area burned, with eight large fires or complexes having burned more than 100000 acres each.

The summer of 2008 was also dry but experienced significantly less fire activity across the US, except for California and parts of the southern US. Northern California, part of which is in the AIRPACT-3 domain, reported over 850000 acres burned, which was nearly 9 times the 10-year average for that region. On 20-21 June 2008, widespread lightning started nearly 1000 fires in Northern California and those in remote and difficult terrain burned for many days. Lightning storms in mid-August 2008 also caused numerous large fires in Idaho and Montana. The number of acres burned by state reported by the NICC NIFC is shown in Table 1 for 2007 and 2008. Analysis of $\mathrm{O}_{3}$ and particulate matter enhancements at the Mt. Bachelor Observatory by Wigder et al. (2013) identified 14 individual fire plumes in 2008 and 6 in 2007. 
Table 1. Total annual fires and acres burned by state.

\begin{tabular}{lrrrr}
\hline \multirow{2}{*}{ State } & \multicolumn{2}{c}{2007} & \multicolumn{2}{c}{2008} \\
& Total fires & Total acres & Total fires & Total acres \\
\hline California & 10034 & 1160297 & 6670 & 1456758 \\
Idaho & 2064 & 2226769 & 1546 & 225832 \\
Montana & 2342 & 859977 & 1749 & 211593 \\
Nevada & 924 & 905237 & 491 & 90868 \\
Oregon & 3424 & 758740 & 2561 & 252671 \\
Utah & 1527 & 664754 & 1139 & 66170 \\
Washington & 2578 & 249708 & 1418 & 154368 \\
USA grand totals & 110237 & 12899948 & 88059 & 7433094 \\
\hline
\end{tabular}

NIFC sources:

http://www.nifc.gov/fireInfo/fireInfo_stats_YTD2007.html

http://www.nifc.gov/fireInfo/fireInfo_stats_YTD2008.html

The analysis presented here includes results for two separate time periods: 3 July-22 August 2007 and 22 June27 August 2008, which were chosen to include the largest annual fire events in the AIRPACT-3 domain. Details about each reported fire complex that burned during the analysis period are given in Table S1 of the Supplement. Fire events during the analysis periods that included at least one reported fire over 5000 acres of burn area are shown in Fig. 1 (Supplement Fig. S1 includes labels for fire complex names).

\section{Methods}

\subsection{AIRPACT-3 air quality modeling system}

The AIRPACT-3 modeling system (Chen et al., 2008; Herron-Thorpe et al., 2010, 2012) simulates air quality in the Pacific Northwest with the CMAQ v4.6 chemical transport model (Byun and Schere, 2006). Area and non-road mobile emissions are from the 2002 EPA NEI, projected to 2005 using the EPA's Economic Growth Analysis System (EGAS) software; on-road mobile emissions are based on the EPA MOBILE v6.2; anthropogenic emissions for Canada are from the 2000 Greater Vancouver Regional District (GVRD) inventory; and biogenic emissions are obtained from the Biogenic Emissions Inventory System version 3 (BEIS-3). The AIRPACT-3 base emissions are spatially and temporally allocated using the Sparse Matrix Operator Kernel Emissions (SMOKE) v2.4 model while all fire emissions are processed with the SMOKE v2.7 model. The AIRPACT-3 domain includes a $95 \times 95$ grid of $12 \mathrm{~km} \times 12 \mathrm{~km}$ cells using 21 layers from the surface to the lower stratosphere. The version of CMAQ used includes the SAPRC-99 chemical kinetic mechanism, the ISOROPIA inorganic aerosol equilibrium module, and the Secondary Organic Aerosols Model (SORGAM). Meteorology inputs for AIRPACT-3 were derived from forecasts by Mass and colleagues (http://www. atmos.washington.edu/mm5rt/; Mass et al., 2003) and preprocessed for CMAQ using the Meteorology Chemistry In- terface Processor (MCIP). The Mesoscale Model v5 (MM5; Mass et al., 2003) was used for the year 2007 simulations while the Weather Research and Forecasting (WRF; Skamarock et al., 2005) model was used for the year 2008 simulations. Model of OZone And Related Tracers, version 4 (MOZART-4; Emmons et al., 2010) simulations produced at the National Center for Atmospheric Research (NCAR) were used as chemical boundary conditions around the AIRPACT3 domain (Emmons et al., 2010; Herron-Thorpe et al., 2012). The MOZART-4 simulations included the assimilation of satellite CO column v4 retrievals from the Measurement Of Pollution In The Troposphere (MOPITT) instrument, a gascorrelation radiometer on-board the NASA Terra satellite (Deeter et al., 2010). The MOZART-4 emissions are the same as those used in Wespes et al. (2012), which include anthropogenic emissions based on the inventory developed by $\mathrm{D}$. Streets for the NASA ARCTAS experiment (http://bio.cgrer. uiowa.edu/arctas/emission.html) and biomass burning emissions from FINN (Fire Inventory from NCAR, Wiedinmyer et al., 2011).

Fire location, area, and emissions were calculated using BlueSky v3.1 data (http://www.airfire.org/bluesky), which utilizes United States Forest Service fire reports and hotspot detects reported by the Hazard Mapping System (HMS) together in the Satellite Mapping Automated Reanalysis Tool for Fire Incident Reconciliation (SMARTFIRE; Larkin et al., 2009 and Raffuse et al., 2009). SMARTFIRE reports wildfire locations (Larkin et al., 2009; Strand et al., 2012), but is ultimately limited by the accuracy and completeness of the satellite detects and US Fire Service (USFS) reports filed. Air quality forecasts use the fire locations reported over the past $48 \mathrm{~h}$ and assume them to persist throughout the simulation. However, the fire reports used in this model reanalysis are from the final SMARTFIRE archive, as distinct from the information reported in near real-time, which allows us to scrutinize the model performance independent of the near real-time fire reporting system. 


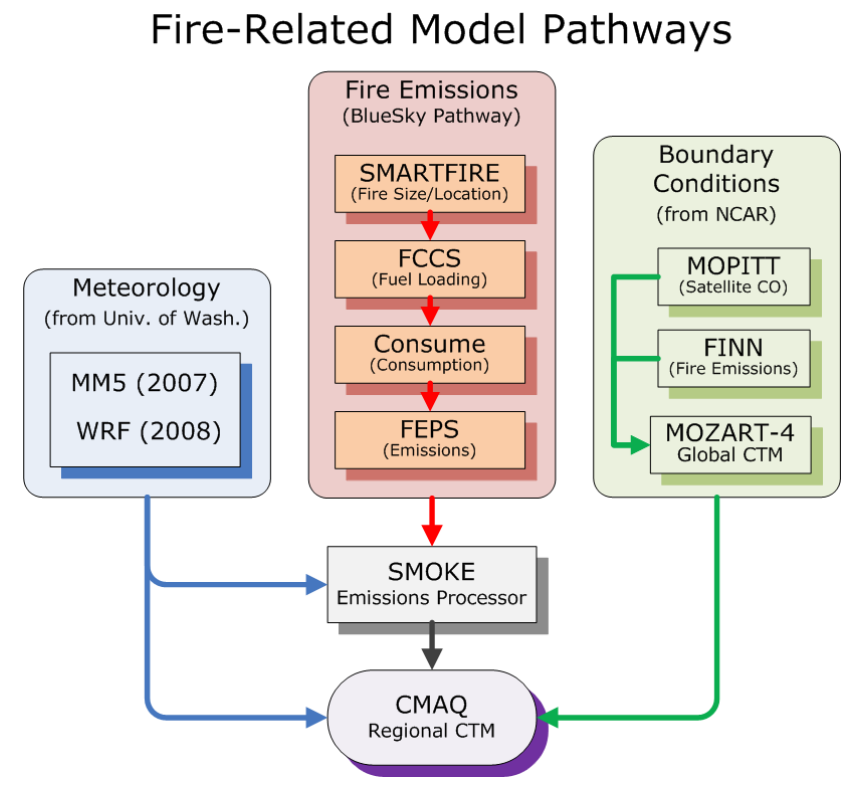

Figure 2. Fire-related modeling pathways used in the AIRPACT-3 simulations.

For this analysis, the BlueSky framework (Larkin et al., 2009; Raffuse et al., 2009) was operated in default mode, which includes the use of the Consume v3 (Ottmar et al., 2009), Fuel Characteristic Classification System v1 (FCCS; Riccardi et al., 2007), and Fire Emission Production Simulator v1 (FEPS; Anderson et al., 2004) software programs provided by the USFS. FCCS v1 provides vegetation type and corresponding fuels (Fig. 1) at $1 \mathrm{~km}$ resolution based on Bailey ecoregions and satellite-derived cover type, which provides input to Consume. Consume was developed empirically using a variety of vegetation types and fire conditions, providing fuel consumption and emissions by combustion phase (smoldering or flaming) data to FEPS. FEPS calculates the heat released and the individual pollutant emissions, based on combustion efficiency of the burn. The default behavior of BlueSky classifies fuels as "dry", unless otherwise reported by SMARTFIRE. This can result in large overpredictions during events that don't consume most available fuels, but generally it is reasonable to assume that fire activity occur in areas with dry fuels. A summary of the fire-related model pathways used for AIRPACT-3 is shown in Fig. 2.

Two plume-rise methods were used in this analysis, resulting in two sets of AIRPACT-3 model results. The first method uses the SMOKE-ready files created by BlueSky, which include hourly information, to explicitly set the plume rise to what FEPS predicts. The second set of model simulations were performed using methods that bypassed the FEPS plume-rise algorithm and instead converted standard BlueSky output to create daily input files for SMOKE. It is important to note that the two plume-rise methods used are based upon the same heat flux and smoldering/flaming emis- sions ratios but the results differ in two ways: (1) whereas FEPS plume-rise method allocates all smoldering emissions to the surface layer, the SMOKE plume-rise method allows for smoldering emissions to be allocated throughout multiple layers near the surface; and (2) whereas FEPS plumerise method does not utilize meteorology or surface elevation when predicting flaming plume heights, the SMOKE plumerise method computes flaming plume heights as a function of buoyancy using the heat content predicted by BlueSky, modeled meteorology, and modeled terrain heights (Pouliot et al., 2005).

\subsection{AQUA-MODIS AOD}

The Aqua satellite was launched in May 2002 carrying the Moderate Resolution Imaging Spectroradiometer (MODIS) as part of NASA's Afternoon-Train (A-Train) of Earth observing satellites (EOS). The Aqua-MODIS retrievals provide aerosol information at nearly the same time as the other A-Train instruments, allowing coincident multi-species analyses, as presented in this analysis. Aqua MODIS reliably retrieves aerosol optical depth (AOD; $\tau$ ) for much of the globe on a daily basis with a nadir footprint of $10 \mathrm{~km}$. Algorithms described by Remer et al. (2005) are used to interpolate the $470 \mathrm{~nm}$ and $660 \mathrm{~nm}$ retrievals to provide a $550 \mathrm{~nm}$ AOD product (MYD04_L2 v5.1; Land_and_Ocean) where only the highest quality data (Quality Flag $=3$ ) is used. Typical AOD values at a clean site are below 0.3 , while values over 1.0 are indicative of multiple scattering caused by high aerosol loading (i.e., heavy haze, biomass burning, or dust events). The maximum AOD values historically retrieved by MODIS are $\sim 5.0$, but these are rare events. MODIS AOD error is not reported for each pixel but studies have validated the an error of $15 \%$, which is influenced by unique aerosol composition, varied land cover color, cloud fringes, and snow cover at high elevations (Levy et al., 2007 and Drury et al., 2008). MODIS AOD retrievals are useful in areas with no clouds but they have been shown to be biased low, compared to AERONET and MISR (Kahn et al., 2010 and Eck et al., 2013).

All MODIS AOD retrievals used in this analysis were projected to the AIRPACT- 3 grid by using the pixel with the closest proximity to the center of each AIRPACT-3 gridcell. This method gives a more detailed map than would otherwise be calculated using weighted spatial interpolation, and is suitable here since the MODIS spatial resolution is finer than AIRPACT-3. AIRPACT-3-simulated aerosol distributions were generated for all modeled aerosol species: nitrates; sulfates; ammonium; elemental carbon (EC); organic particulates; and coarse mode aerosols. AOD was calculated from AIRPACT-3 simulated aerosol species concentrations and size distributions using algorithms developed by Binkowski and Roselle (2003). This method uses the simulated aerosol total volume concentration for the Aitken and accumulation mode aerosols and their associated Mie extinc- 
tion efficiencies to calculate AOD per modeled layer, which is then integrated vertically through the troposphere to yield the reported model AOD. An accurate approximation method from Evans and Fournier (1990) was used to calculate the Mie extinction efficiency factors. AIRPACT-3 grid-cells that did not have corresponding high-quality MODIS retrievals were omitted from the analysis.

\subsection{OMI tropospheric $\mathrm{NO}_{2}$}

The Aura satellite successfully joined the A-Train in July 2004, carrying multiple instruments that retrieve information about atmospheric chemistry. Although tropospheric ozone retrieved by the Ozone Monitoring Instrument (OMI) is typically not precise enough for this wildfire analysis, the tropospheric $\mathrm{NO}_{2}$ columns provided by the Tropospheric Emission Monitoring Internet Service (TEMIS; http://www. temis.nl/airpollution/no2.html) are of significant value. The Derivation of OMI tropospheric $\mathrm{NO}_{2}$ (DOMINO) algorithms calculate air mass factors (AMF), a priori profiles, stratospheric $\mathrm{NO}_{2}$, and ghost columns from the daily global Tracer Model v4 (TM4), which is driven with meteorological fields from the European Centre of Medium-Range Forecasts (ECMWF) (Boersma et al., 2011). The product provides tropospheric $\mathrm{NO}_{2}$ column retrievals with a $13 \mathrm{~km} \times 24 \mathrm{~km}$ footprint at nadir with increasing footprint size as the observation moves off-nadir. A pixel's "ghost column" (below cloud) is estimated from the a priori profile for the pixel and OMI's retrieval of $\mathrm{NO}_{2}$ above the cloud cover pressure level, with vertical sensitivity defined by the averaging kernel. The sum of the OMI ghost column and tropospheric column can be compared to a model column for an estimate of model performance. However, when the model $\mathrm{NO}_{2}$ profile is convolved with the averaging kernel, the ghost column is no longer required. Typical reported errors in the DOMINO product are lowest $(\sim 25 \%)$ where there is a large signal (e.g., over $2^{\circ} 10^{15}$ molec. $\mathrm{cm}^{-2}$ ) but errors are typically much higher $(\sim 50 \%)$ when the signal is considerably less.

Since OMI's $\mathrm{NO}_{2}$ averaging kernel shows decreasing sensitivity as the vertical profile approaches the surface, the result of applying the averaging kernel to AIRPACT-3 $\mathrm{NO}_{2}$ allows for essentially a "free troposphere" comparison with OMI. In this study we used OMI pixels with low cloud fraction $(<35 \%)$ and convolved all AIRPACT-3 profiles with the OMI averaging kernel. AIRPACT-3 cells that fall within the spatial boundaries of each OMI pixel were averaged and interpolated, effectively reducing the resolution of the model results to equal that of the co-located OMI pixel, and then both were interpolated to the original AIRPACT-3 projection using a Delaunay triangulation scheme. This method works well for most areas but can lead to inconsistencies over areas with complex terrain (Herron-Thorpe et al., 2010). Comparisons of CMAQ $\mathrm{NO}_{2}$ to satellite retrievals also have inherent uncertainty associated with the rapid conversion of $\mathrm{NO}_{\mathrm{x}}$ to PAN and nitrate (Alvarado et al., 2010 and Akagi et al., 2012).

\subsection{AIRS CO}

The Aqua satellite includes the Atmospheric Infra-Red Sounder (AIRS), which provides information about weather and trace gases. The AIRS instruments are an infrared spectrometer and a visible light/near-infrared photometer. The AIRS total column carbon monoxide level-2 v5 product used in this analysis (AIRX2RET) provides data reported on the Advanced Microwave Sounding Unit (AMSU) ground footprint, which varies from $36 \mathrm{~km} \times 36 \mathrm{~km}$ to $50 \mathrm{~km} \times 50 \mathrm{~km}$. AIRS level-2 v5 data includes 7 trapezoidal layers of CO mixing ratio in the troposphere and an averaging kernel matrix for the full 9-layer profile available in the support product files. In this study, the AIRPACT-3 profiles were convolved with the AIRS averaging kernels as discussed in Olsen et al. (2007) and Maddy and Barnet (2008), and the total column $\mathrm{CO}$ values were then interpolated to the original AIRPACT-3 projection using a Delaunay triangulation scheme. The AIRS averaging kernel slightly reduces the AIRPACT-3 total column CO, with some loss of information in the lower troposphere and enhanced middle troposphere sensitivity (Herron-Thorpe et al., 2012). AIRS typically has only 1 degree of freedom in the troposphere, with its greatest sensitivity to the mid-troposphere. Thus AIRS retrievals likely underestimate total column $\mathrm{CO}$ for fire plumes contained within a shallow boundary layer. However, the convolution of the model with the AIRS averaging kernels should address potential comparison problems. The typical reported error in the AIRS CO product varies by layer, with moderate error $(\sim 45 \%)$ throughout the middle and upper troposphere and even larger error $(\sim 60 \%)$ in the lower troposphere. However, large $\mathrm{CO}$ values (e.g., greater than $2.3^{\circ} 10^{18}$ molec. $\mathrm{cm}^{-2}$ ), as the case with large fire plumes, are typically associated with very low errors (10-20\%) throughout the layers.

\subsection{CALIOP aerosol detection}

The Cloud Aerosol LIDAR and Infrared Pathfinder Satellite Observation (CALIPSO) satellite successfully joined the ATrain in April 2006, carrying the Cloud-Aerosol LIDAR with Orthogonal Polarization (CALIOP) instrument as its main payload. CALIOP transmits a linearly polarized laser pulse and then detects the light that is reflected back. Determining the aerosol type from this space-based LIDAR depends on the attenuated backscatter, altitude, location, surface type, and the volume depolarization (ratio of the perpendicular backscatter to the parallel backscatter of the laser light retrieved). Detailed information about the CALIOP data is in the CALIPSO Users Guide (http://www-calipso.larc.nasa. gov/resources/calipso_users_guide/). The laser beam diameter of CALIOP is $\sim 90 \mathrm{~m}$ at the Earth's surface, combined 
Table 2. Definitions of model performance statistics (Chen et al., 2008).

\begin{tabular}{ll}
\hline Measured concentration & $O_{i}$ \\
Predicted concentration & $M_{i}$ \\
Number of paired data points & $N$ \\
\hline Predicted mean $(\bar{M})$ & $\frac{1}{N} \sum_{i=1}^{N} M_{i}$ \\
Measured mean $(\bar{O})$ & $\frac{1}{N} \sum_{i=1}^{N} O_{i}$ \\
Mean bias (MB) & $\frac{1}{N} \sum_{i=1}^{N}\left(M_{i}-O_{i}\right)$ \\
Mean error (ME) & $\frac{1}{N} \sum_{i=1}^{N}\left|M_{i}-O_{i}\right|$ \\
Normalized mean bias (NMB) & $\frac{1}{N} \sum_{i=1}^{N}\left(M_{i}-O_{i}\right) / O_{i}$ \\
Normalized mean error (NME) & $\frac{1}{N} \sum_{i=1}^{N}\left|M_{i}-O_{i}\right| / O_{i}$ \\
Fractional bias (FB) & $\frac{1}{N} \sum_{i=1}^{N} \frac{\left(M_{i}-O_{i}\right)}{0.5\left(M_{i}+O_{i}\right)}$ \\
Fractional error (FE) & $\frac{1}{N} \sum_{i=1}^{N} \frac{\left|M_{i}-O_{i}\right|}{0.5\left(M_{i}+O_{i}\right)}$ \\
Correlation coefficient $(r)$ & $\frac{\sum_{i=1}^{N}\left(M_{i}-\bar{M}\right)\left(O_{i}-\bar{O}\right)}{\left[\sum_{i=1}^{N}\left(M_{i}-\bar{M}\right)^{2} \cdot \sum_{i=1}^{N}\left(O_{i}-\bar{O}\right)^{2}\right]^{1 / 2}}$ \\
\hline
\end{tabular}

with a horizontal resolution along scan that varies from $333 \mathrm{~m}$ (surface) to $1 \mathrm{~km}(8.5 \mathrm{~km}$ to $20 \mathrm{~km}$ altitude). The v3.01 CALIOP level-2 Vertical Feature Mask (Liu et al., 2005; Mielonen et al., 2009; and Winker et al., 2009) product available from the NASA Langley Research Center Atmospheric Science Data Center was used to evaluate AIRPACT3 plume top height performance. We evaluated plume top heights above mean sea level (AMSL) and above ground level (AGL), so that discrepancies in terrain height could be evaluated. For this analysis, we consider AGL plume heights to be relative to the ground level reported by the respective data set.

\subsection{Daily remote sensing activity}

In addition to the methods described above, we also assessed overall fire conditions using MODIS true-color imagery of smoke plumes with markers for hot-spot locations, available from the Land Atmosphere Near Real-time Capability for EOS (LANCE; USA subset 1; http://lance-modis. eosdis.nasa.gov/imagery/subsets/index.php?project=fas). A daily remote sensing $\log$ of the LANCE-MODIS imagery and corresponding remote sensing comparisons, derived from the AIRPACT-3 FEPS plume-rise scenario, was also compiled (Tables S2-S5). Each fire region that was significantly over the signal-to-noise threshold was counted and tallied in the daily remote-sensing log for AOD and tropospheric $\mathrm{NO}_{2}$ comparisons. AIRS resolution did not allow us to identify "distinguishable events" and were not tallied. The horizontal footprint and sensitivity of each remote sensing instrument varies, thus distinguishable events counted in the log ranged from strong isolated fires to large areas with numerous mixed plumes.

\subsection{Model performance statistics and ground-site selection}

Definitions of the model performance statistics used are shown in Table 2. Guidance on the treatment of negative values in satellite products suggests that long-term studies (e.g., with time-averaging) should retain the negative values so that no artificial bias is introduced for clean conditions (see http://modis-atmos.gsfc.nasa.gov/MOD04_L2/ format.html). However, we were interested in short-term pollution events and chose to discard negative OMI and MODIS values. This approach helped us avoid spurious fractional statistics because it allowed little signal from the variance in "unpolluted" satellite retrievals and focused our statistics on "polluted" events. To assess the model performance for wildfire impacts, the ground-site analysis presented here uses combinations of 140 US surface monitor locations where AIRPACT-3 predicted more than double the normal surface $\mathrm{PM}_{2.5}$ levels sometime during the analysis as an indicator of wildfire impacts. Surface monitor data sets that were excluded from the analysis had one or more of the following problems: no quality-controlled hourly data set was available; the site was primarily indicative of urban emissions; the site was in Canada (AIRPACT-3 has no wildfire emissions in the Canadian part of the domain); or the site exhibited no distinguishable increase in surface $\mathrm{PM}_{2.5}$ during fire events. The 2007 analysis period had 67 qualified $\mathrm{PM}_{2.5}$ sites and 10 qualified ozone sites; while the 2008 analysis period had 82 qualified $\mathrm{PM}_{2.5}$ sites and 18 qualified ozone sites. The primary analysis of AOD, tropospheric column $\mathrm{NO}_{2}$, and total column CO includes all 140 site locations. For the purpose of generating model performance statistics, we assessed model performance at these discrete site locations rather than across the entire domain. This was done so that surface monitor observations and satellite retrievals could be compared more consistently, and so that the randomness of the location of usable retrievals did not skew our results spatially or with urban signatures. A more selective rural-sites-only subset includes 43 locations with no possible influence of transported urban pollution in the remote sensing records. This ruralsites-only subset is used for the "matched-threshold" analysis to help determine model performance for fire-polluted cases, by only including instances where AIRPACT-3 and the monitor/retrieval in question both surpassed a threshold value: $10 \mu \mathrm{g} \mathrm{m}^{-3}$ for the average $24 \mathrm{~h}$ surface $\mathrm{PM}_{2.5} ; 0.3$ for AOD; $1.0^{\circ} 10^{15}$ molec. $\mathrm{cm}^{-2}$ for tropospheric column $\mathrm{NO}_{2}$; and $1.9^{\circ} 10^{18}$ molec. $\mathrm{cm}^{-2}$ for total column CO.

All surface monitor comparisons in this analysis (Fig. S2) were made using hourly data from the EPA Air Quality System (http://www.epa.gov/ttn/airs/airsaqs/detaildata/ downloadaqsdata.htm), except for data from Mt. Bachelor Observatory (MBO) in the Oregon Cascade mountains, which is not an AQS reporting site. The Mt. Bachelor Observatory has been used to collect air quality data since 2004, including near-continuous observations of $\mathrm{CO}, \mathrm{O}_{3}$, aerosol 
scattering and meteorological parameters, and various other chemical species during intensive campaigns. MBO is located at coordinates $43.98^{\circ} \mathrm{N}, 121.69^{\circ} \mathrm{W}$ at an elevation of $2.7 \mathrm{~km}$. The site has been used to investigate long-range transport of Asian pollution and biomass burning, regional wildfires, and other events including stratospheric intrusions (Weiss-Penzias et al., 2006; Ambrose et al., 2011; Wigder et al., 2013). AIRPACT-3 $\mathrm{PM}_{2.5}$ and carbon monoxide concentrations were extracted from the layer corresponding to a height of $2.7 \mathrm{~km}$ AMSL in the model for comparisons to Mt. Bachelor Observatory to account for the discrepancy in model surface height.

\section{Results}

Remote sensing of atmospheric gases and aerosols is limited by cloud conditions and the source signal strength at the relevant infrared/visible/UV wavelengths. Maps of AOD, tropospheric $\mathrm{NO}_{2}$ column, and total carbon monoxide column for analysis days in 2007 (2008) with favorable remote-sensing conditions are shown in Figs. $3,4(5,6)$ for the SMOKE plume-rise scenario (see Figs. S3-S8 for the FEPS plumerise scenario).

On 22 July 2007, AIRPACT-3 under-predicted AOD related to fires in Montana, southern Idaho, and Nevada (Figs. 3, S3). AIRPACT-3 also under-predicted tropospheric column $\mathrm{NO}_{2}$ in Nevada and Montana on 22 July 2007 but the largest modeled fires were not observed via remote sensing, in central Idaho near the Montana border, likely due to mismatch in timings of fire emissions and satellite detections. Data from 12 August (Figs. 4, S4) and $18 \mathrm{Au}-$ gust (Fig. S5a, S5b) show typical AIRPACT-3 comparisons during the largest fire periods in 2007. AIRPACT-3 underestimated the fire-generated pollutants from N. California on 29 June 2008 (Figs. 5, S6) and missed pollutants transported from outside of the domain. AIRPACT-3 did better predicting fires in N. California on 11 July 2008 (Fig. S7a, S7b) but continued to miss fire-generated pollutants from outside of the domain. This is especially evident in Nevada when firegenerated AOD originating from south of the AIRPACT-3 domain is observed but not predicted, suggesting that boundary conditions derived from the MOZART-4 simulations under-predict the influence of fires from outside the domain. AIRPACT-3 did well predicting an interesting transport case on 20 July 2008 but over-predicted the near-source pollutants in N. California/S. Oregon while under-predicting the transported aerosol from within the domain and over-predicting the transported $\mathrm{CO}$ from within the domain (Figs. 6, S8). In general, fire locations and air quality impacts were predicted well near fire sources, but AOD predictions were often too low in regions beyond $100 \mathrm{~km}$ downwind of large fires. Furthermore, AIRPACT-3 did not predict the observed fire impacts in Nevada that were transported from south of the domain.
The daily AOD Log for 2007 (2008) discussed in Table S2 (S4) notes that there were 44 (64) days in the period analyzed that confidently showed MODIS AOD due to fires: of the 176 (108) total discernible events, $8 \%$ (6\%) were observed but not predicted; $37 \%$ (32\%) were under-predicted; $30 \%(31 \%)$ were predicted well; $20 \%$ (18\%) were overpredicted; and $5 \%(13 \%)$ were predicted but not observed. We found that the magnitude of predicted AOD that extended to large distances from sources inside the domain was underpredicted for $13 \%$ (31\%) of discernible events. Additionally, we found that the magnitude of predicted AOD from sources outside the domain was under-predicted during 8 (27) of the 44 (64) days. There were also 2 (3) days where MODIS AOD clearly showed aerosol loading retained from the previous day that were not predicted. The Daily $\mathrm{NO}_{2} \log$ for 2007 (2008) in Table S3 (S5) also notes that there were 31 (44) days in the period analyzed that confidently showed tropospheric $\mathrm{NO}_{2}$ due to fires: of the 122 (76) total discernible events, $0 \%(4 \%)$ were observed but not predicted; $23 \%$ $(13 \%)$ were under-predicted; $21 \%(30 \%)$ were predicted well; $48 \%$ (37\%) were over-predicted; and $8 \%(16 \%)$ were predicted but not observed. There was also one day (1 July 2008) where OMI clearly showed tropospheric $\mathrm{NO}_{2}$ loading retained from the previous day that was not predicted.

Overall, AIRPACT was biased low for all analyzed pollutants for both the 2007 and 2008 timelines. In comparison, for non-fire periods across the whole domain, AIRPACT tends to over-estimate long-term average $\mathrm{PM}_{2.5}$ levels by $\sim 3 \%$ (Chen et al., 2008). The 2007 (2008) fractional biases of the SMOKE plume-rise scenario for all 140 sites were $-61 \%(-53 \%)$ for AOD, $-39 \%(-28 \%)$ for tropospheric column $\mathrm{NO}_{2}$, and $-10 \%(-5 \%)$ for total column $\mathrm{CO}$. The FEPS plume-rise scenario changed results by a few percent with fractional biases of $-66 \%(-58 \%),-38 \%(-26 \%)$, and $-13 \%(-7 \%)$, respectively (Table 3$)$. In comparison, the fractional biases for the matched-threshold analysis of the SMOKE plume-rise scenario for all 43 rural sites (where both the model and satellite retrieval were greater than 0.3 AOD, $1.010^{15} \mathrm{VCD} \mathrm{NO}_{2}$, or $\left.1.910^{18} \mathrm{VCD} \mathrm{CO}\right)$ were $-101 \%(-105 \%),-98 \%(-93 \%)$, and $-10 \%(-9 \%)$, respectively. The fractional biases for the matched-threshold analysis of the FEPS plume-rise scenario were $-117 \%$ $(-125 \%),-97 \%(-90 \%)$, and $-18 \%(-12 \%)$, respectively (Table 4). The biases in total column $\mathrm{CO}$ are within the reported retrieval error, and thus are not significant. The low tropospheric $\mathrm{NO}_{2}$ biases were greater in magnitude than the reported retrieval errors, and mostly driven by the lack of $\mathrm{NO}_{2}$ coming in from south of the domain. The low AOD biases were much greater in magnitude than the expected retrieval error, indicating persistent problems with AIRPACT-3 aerosol predictions. 

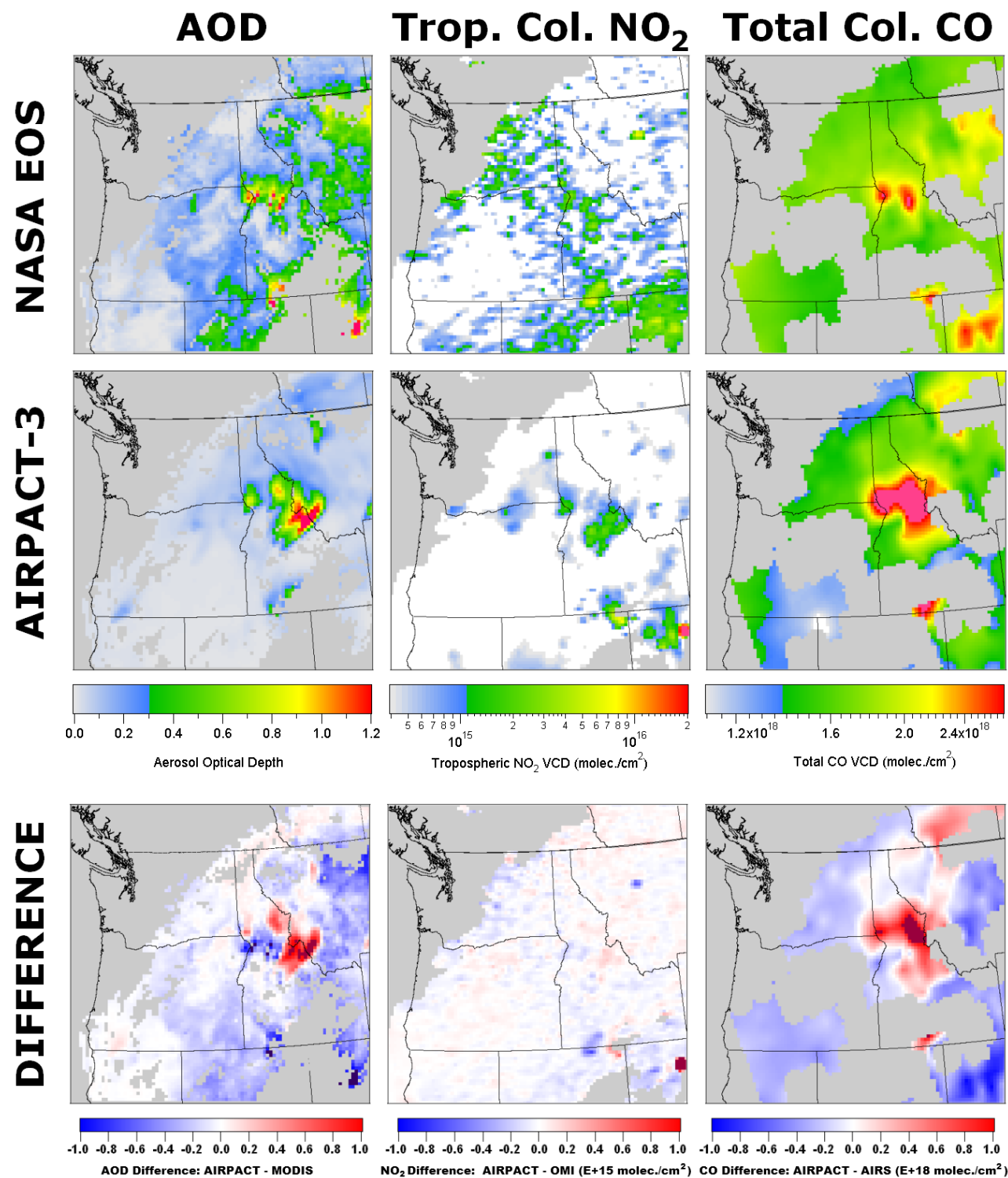

Figure 3. AOD (left column), tropospheric $\mathrm{NO}_{2}$ columns (middle column), and total carbon monoxide columns (right column) for 22 July 2007 ( 2 p.m. LST) with NASA EOS retrieval (top row), AIRPACT-3 with SMOKE plume rise (middle row), and differences (bottom row). Gray color indicates no or low-quality data from the satellite retrieval and exclusion from analysis. Values greater than the color scale maximum are shown as pink in the AIRPACT-3 and NASA EOS maps. Values outside the range of the difference color scales are shown as saturated blue/red.

CALIOP retrievals were compared to AIRPACT aerosols across the model domain when CALIPSO passed over the Idaho and California wildfire smoke plumes during the analysis periods of 2007 and 2008, respectively. There were many instances where both AIRPACT-3 and CALIOP showed the presence of fire-related aerosol pollution at similar heights. In 2007 (2008), CALIOP retrievals showed aerosol pollution over 328 (383) unique AIRPACT grid cells across Nevada, Idaho, and Canada (California, Oregon, Washington, and Canada), while 218 (281) and 219 (275) of those grid cells had AIRPACT-3 aerosol pollution in the SMOKE and FEPS plume-rise scenarios.

There was moderate linear correlation $\left(r^{2}=0.41\right.$ for FEPS plume rise; $r^{2}=0.50$ for SMOKE plume rise) between AIRPACT-3 and CALIPSO plume top heights AMSL, when both showed the presence of an aerosol subtype (Fig. 7). On average, in 2007 (2008) the AIRPACT3 FEPS plume-rise scenario under-predicted plume top heights AMSL by $3.1 \pm 2.3 \mathrm{~km}(2.5 \pm 1.5 \mathrm{~km})$, while the SMOKE plume-rise scenario under-predicted plume top heights AMSL by $3.1 \pm 2.0 \mathrm{~km}(2.2 \pm 1.6 \mathrm{~km})$. There were 

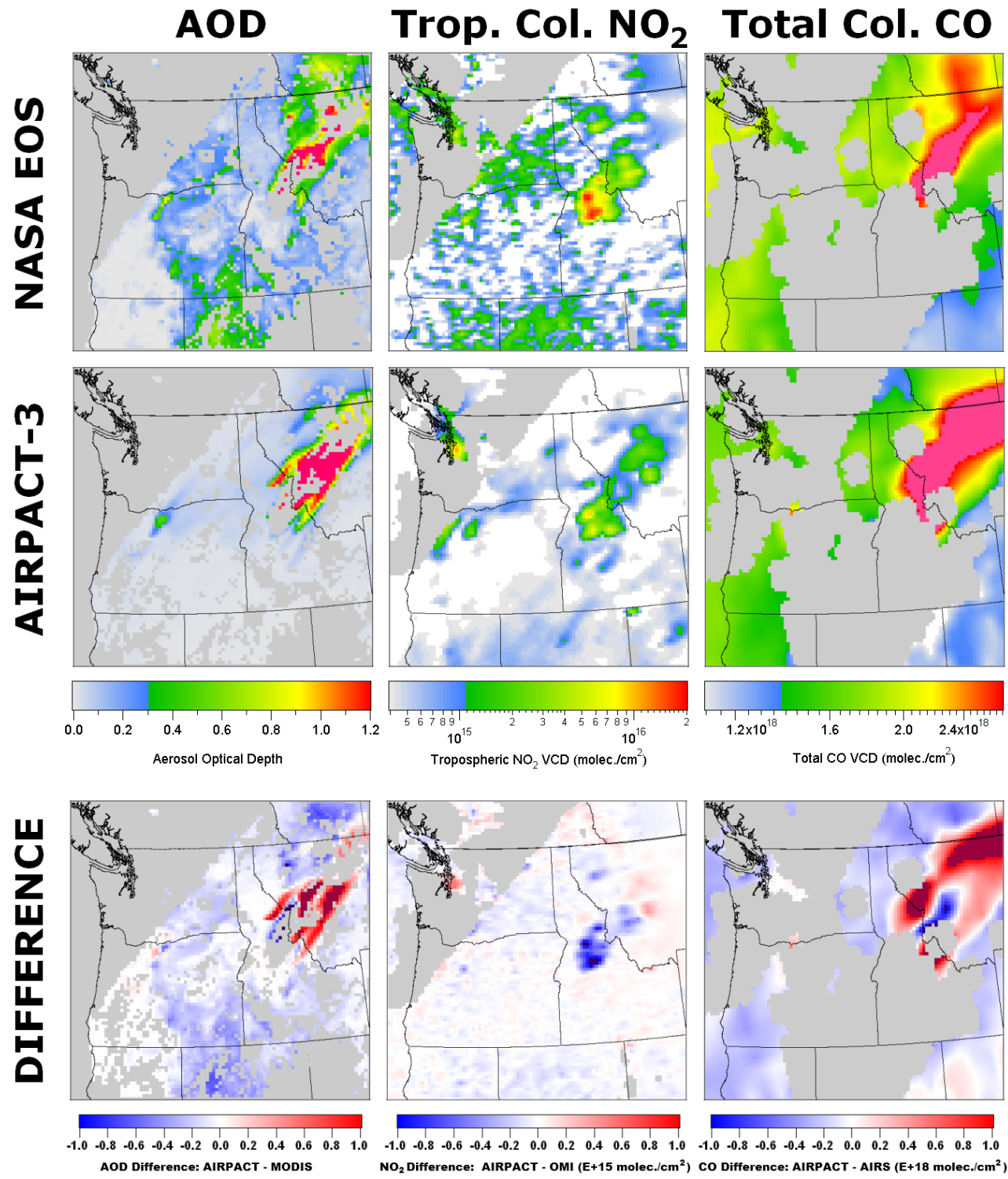

Figure 4. AOD (left column), tropospheric $\mathrm{NO}_{2}$ columns (middle column), and total carbon monoxide columns (right column) for 12 August 2007 ( 2 p.m. LST) with NASA EOS retrieval (top row), AIRPACT-3 with SMOKE plume rise (middle row), and differences (bottom row). Gray color indicates no or low-quality data from the satellite retrieval and exclusion from analysis. Values greater than the color scale maximum are shown as pink in the AIRPACT-3 and NASA EOS maps. Values outside the range of the difference color scales are shown as saturated blue/red.

many instances in which above ground level (AGL) comparisons were reasonable but dissimilar terrain heights resulted in large under-predictions in plume top heights AMSL. The horizontal resolution of AIRPACT smoothes the surface elevation in complex terrain so that it is consistently lower relative to CALIOP retrievals, and is a large source of uncertainty when evaluating AIRPACT plume tops. We found smaller linear correlation $\left(r^{2}=0.18\right.$ for FEPS plume rise; $r^{2}=0.24$ for SMOKE plume rise) between AIRPACT3 and CALIPSO plume tops heights AGL (Table 5 and Fig. 7). On average, though, in 2007 (2008) the AIRPACT-3
FEPS plume-rise scenario under-predicted plume top heights AGL by $1.4 \pm 2.3 \mathrm{~km}(1.0 \pm 1.2 \mathrm{~km})$ while the SMOKE plume-rise scenario under-predicted plume top heights AGL by $1.5 \pm 1.9 \mathrm{~km}(0.9 \pm 1.3 \mathrm{~km})$. This is consistent with a national study using a similar modeling structure, where CMAQ plume heights were under-predicted by $\sim 20 \%$, relative to CALIOP retrievals (Raffuse et al., 2012).

From 3 July to 22 August 2007 (22 June to 27 August 2008) the daily $24 \mathrm{~h}$ average $\mathrm{PM}_{2.5}$ was averaged across 67 (82) sites and the maximum daily $8 \mathrm{~h}$ average ozone was averaged across 10 (18) sites for modeled and measured 

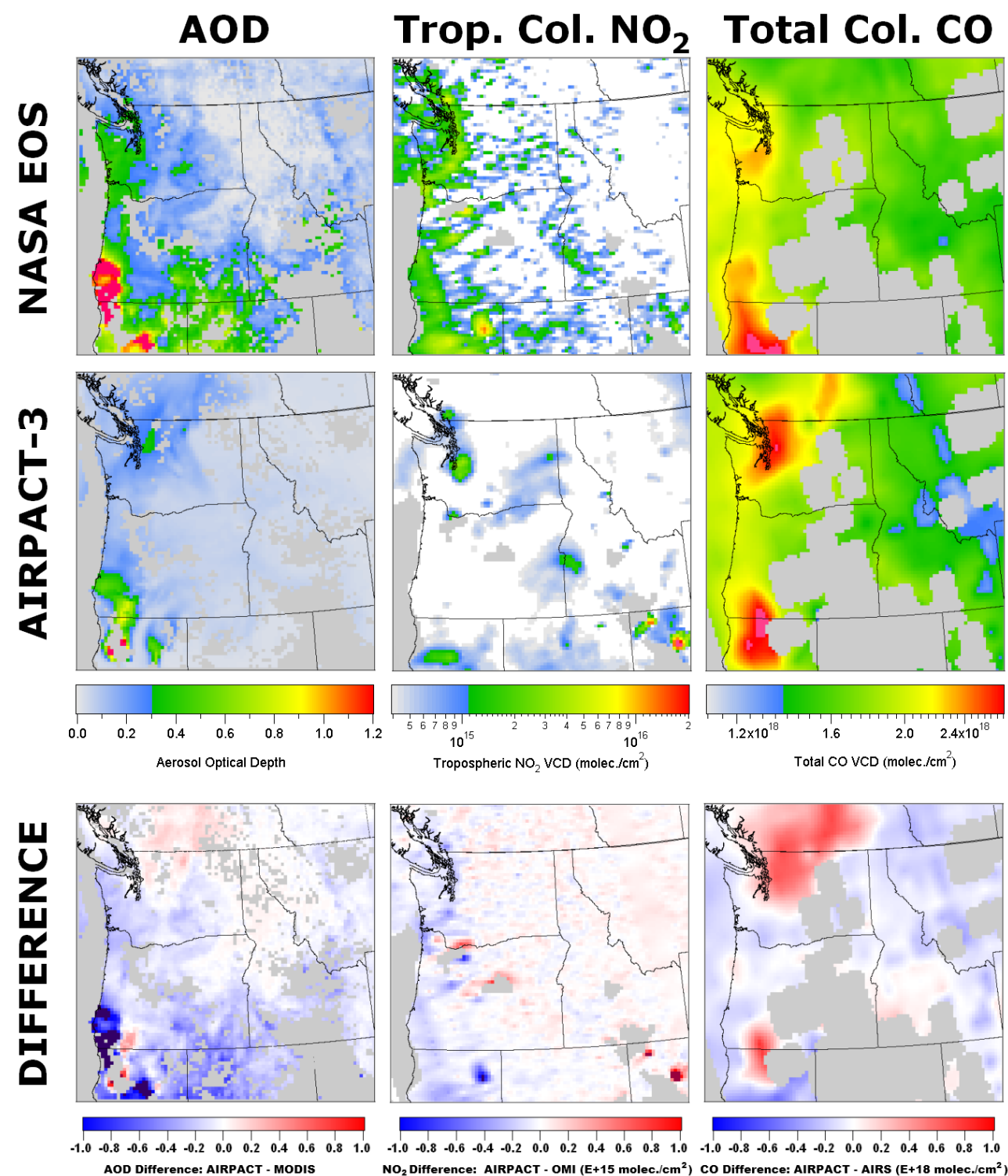

Figure 5. AOD (left column), tropospheric $\mathrm{NO}_{2}$ columns (middle column), and total carbon monoxide columns (right column) for 29 June 2008 ( 2 p.m. LST) with NASA EOS retrieval (top row), AIRPACT-3 with SMOKE plume rise (middle row), and differences (bottom row). Gray color indicates no or low-quality data from the satellite retrieval and exclusion from analysis. Values greater than the color scale maximum are shown as pink in the AIRPACT-3 and NASA EOS maps. Values outside the range of the difference color scales are shown as saturated blue/red.

concentrations. The "all sites" comparison (Fig. 8) shows that maximum daily $8 \mathrm{~h}$ surface ozone was generally underpredicted by $2-8$ ppb in 2007 , which might be expected with simulations of ozone in the presence of aerosols (Alvarado and Prinn, 2009). The maximum daily $8 \mathrm{~h}$ ozone was nearly matched in 2008. In general, AIRPACT-3 predicted changes in ozone that were similar to what was observed across the region. The timeline also shows that AIRPACT-3 generally under-predicted daily surface $\mathrm{PM}_{2.5}$ averages by $2-5 \mu \mathrm{g} \mathrm{m} \mathrm{m}^{-3}$ and followed the measured curve closely except for gross over-prediction of surface $\mathrm{PM}_{2.5}$ concentrations from 14-16 August 2007 and 12-13 July 2008.

\subsection{PM $_{2.5}$ NAAQS comparisons}

AIRPACT-3 daily $24 \mathrm{~h} \mathrm{PM}_{2.5}$ was assessed from a policy standpoint for both the daily $\left(35 \mu \mathrm{g} \mathrm{m}^{-3}\right)$ and annual $\left(12 \mu \mathrm{g} \mathrm{m}^{-3}\right)$ National Ambient Air Quality Standards (NAAQS) threshold values. For each site, we calculated the number of days when both the model results and the observations showed $\mathrm{PM}_{2.5}$ concentrations greater than the NAAQS. We tallied the number of these days during the analysis pe- 

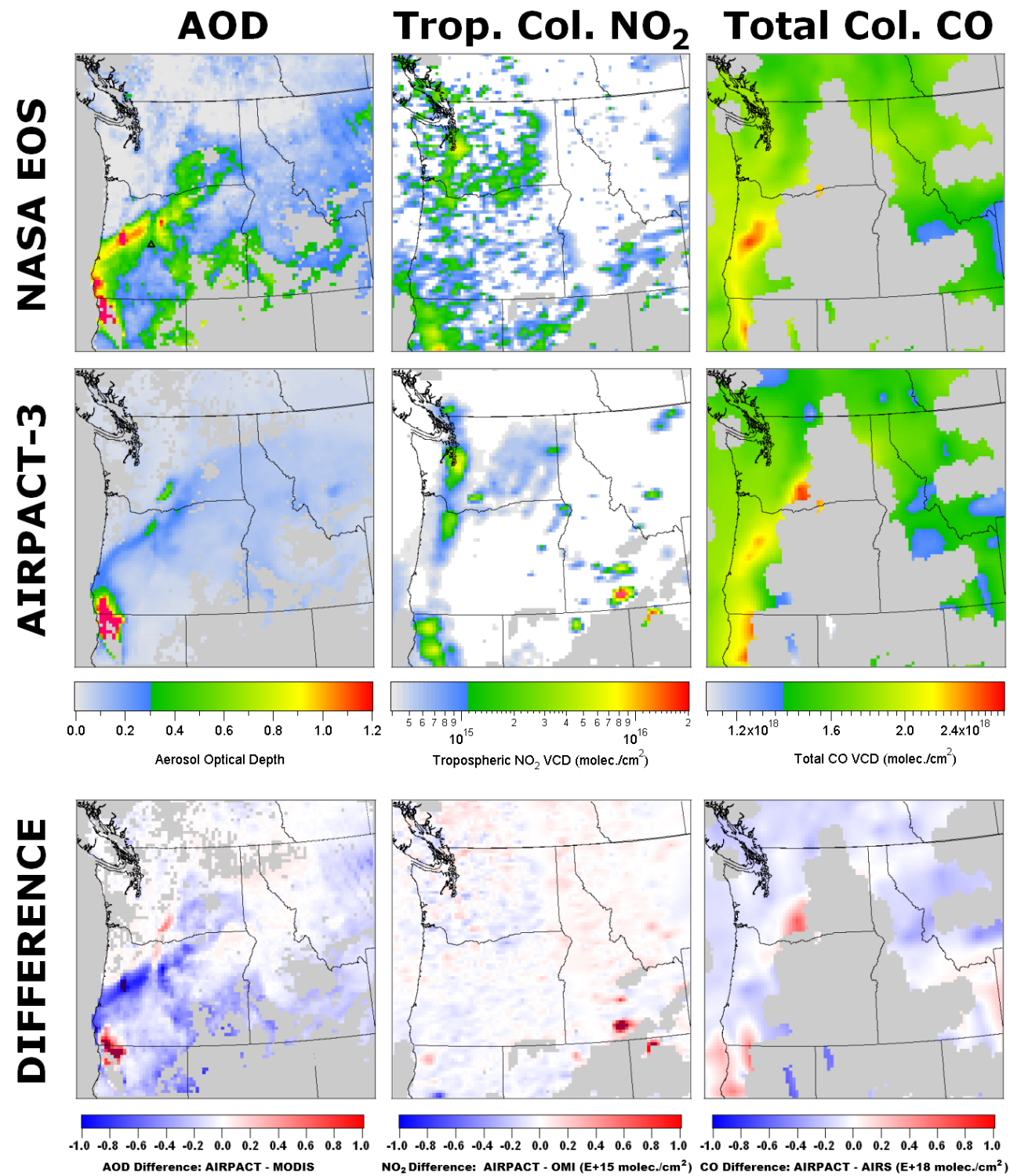

Figure 6. AOD (left column), tropospheric $\mathrm{NO}_{2}$ columns (middle column), and total carbon monoxide columns (right column) for 20 July 2008 ( 2 p.m. LST) with NASA EOS retrieval (top row), AIRPACT-3 with SMOKE plume rise (middle row), and differences (bottom row). Gray color indicates no or low-quality data from the satellite retrieval and exclusion from analysis. Values greater than the color scale maximum are shown as pink in the AIRPACT-3 and NASA EOS maps. Values outside the range of the difference color scales are shown as saturated blue/red. Mt. Bachelor is shown as a black triangle near central Oregon.

riod, for 67 sites in 2007 and 82 sites in 2008. For the FEPS plume-rise scenario we found: $97.7 \%$ of the data pairs were in agreement, with values less than the daily threshold; $0.2 \%$ of the data pairs were in agreement, with values higher than the daily threshold; $0.3 \%$ of the data pairs included observations higher than the daily threshold, with no such model prediction; and $1.8 \%$ of the data pairs included model predictions higher than the daily threshold, with no such observation. The SMOKE plume-rise scenario reduced the number of model predictions that were higher than the daily thresh- old, with no such observation, by $27 \%$ (or $1.3 \%$ of the total data pairs).

In terms of the annual threshold, the FEPS plume-rise scenario showed that: $90.7 \%$ of the data pairs were in agreement, with values less than the annual threshold; $1.8 \%$ of the data pairs were in agreement, with values higher than the annual threshold; $4 \%$ of the data pairs included observations higher than the annual threshold, with no such model prediction; and $3.5 \%$ of the data pairs included model predictions higher than the annual threshold, with no such observations. The SMOKE plume-rise scenario increased the number of 
Table 3. Summary of FEPS plume-rise scenario comparisons (SMOKE plume-rise scenario shown in parentheses when different) from 3 July to 23 August 2007 (top) and 22 June to 27 August 2008 (bottom).

\begin{tabular}{|c|c|c|c|c|c|}
\hline Species & $\begin{array}{r}\mathrm{A} 24 \mathrm{~h} \\
\mathrm{PM}_{2.5} \\
\left(\mu \mathrm{g} \mathrm{m}^{-3}\right)\end{array}$ & $\begin{array}{r}\text { MDA8 h } \\
\text { Ozone } \\
(\mathrm{ppbV})\end{array}$ & AOD & $\begin{array}{r}\text { Tot. Col. CO } \\
\left(10^{18} \text { molec. } \mathrm{cm}^{-2}\right)\end{array}$ & $\begin{array}{r}\text { Trop. Col. } \mathrm{NO}_{2} \\
\left(10^{15} \text { molec. } \mathrm{cm}^{-2}\right)\end{array}$ \\
\hline Observations source & EPA AQS & EPA AQS & MODIS & AIRS & OMI \\
\hline \multicolumn{6}{|l|}{3 July-22 August 2007} \\
\hline Paired points & 3267 & 450 & 3603 & 4275 & 5821 \\
\hline Correlation $(r)$ & $0.5(0.6)$ & 0.7 & $0.4(0.3)$ & $0.6(0.5)$ & 0.4 \\
\hline Measured mean & 7.1 & 45.8 & 0.2 & 1.8 & 1.4 \\
\hline Mean bias & $0.4(-0.72)$ & $-4.6(-3.5)$ & -0.1 & -0.2 & -0.5 \\
\hline Mean error & $5.6(4.1)$ & $8.9(9.0)$ & 0.1 & 0.2 & 0.9 \\
\hline Normalized mean bias (\%) & $-2(-9)$ & $-7(-4)$ & $-23(-15)$ & $-12(-9)$ & $110(104)$ \\
\hline Normalized mean error (\%) & $63(54)$ & $20(21)$ & $77(85)$ & $13(12)$ & $189(182)$ \\
\hline Fractional bias (\%) & $-34(-33)$ & $-10(-8)$ & $-66(-61)$ & $-13(-10)$ & $-38(-39)$ \\
\hline Fractional error (\%) & $60(57)$ & $22(21)$ & $91(90)$ & $14(13)$ & $75(76)$ \\
\hline \multicolumn{6}{|l|}{22 June-27 August 2008} \\
\hline Paired points & 5329 & 1135 & 5125 & 4577 & 7760 \\
\hline Correlation $(r)$ & $0.0(0.4)$ & 0.8 & 0.3 & $0.7(0.6)$ & 0.5 \\
\hline Measured mean & 6.8 & 42.3 & 0.2 & 1.9 & 1.3 \\
\hline Mean bias & $0.3(-0.7)$ & $-0.7(0.2)$ & -0.1 & -0.1 & -0.3 \\
\hline Mean error & $5.4(4.1)$ & $7.7(8.0)$ & 0.1 & 0.2 & 0.8 \\
\hline Normalized mean bias (\%) & $34(5)$ & $3(5)$ & $-9(18)$ & $-7(-4)$ & $110(106)$ \\
\hline Normalized mean error (\%) & $98(66)$ & 21 & 85 (108) & 9 & $176(173)$ \\
\hline Fractional bias (\%) & $-31(-27)$ & $-1(1)$ & $-58(-53)$ & $-7(-5)$ & $-26(-28)$ \\
\hline Fractional error (\%) & $62(60)$ & 20 & $88(84)$ & $9(10)$ & 70 \\
\hline
\end{tabular}
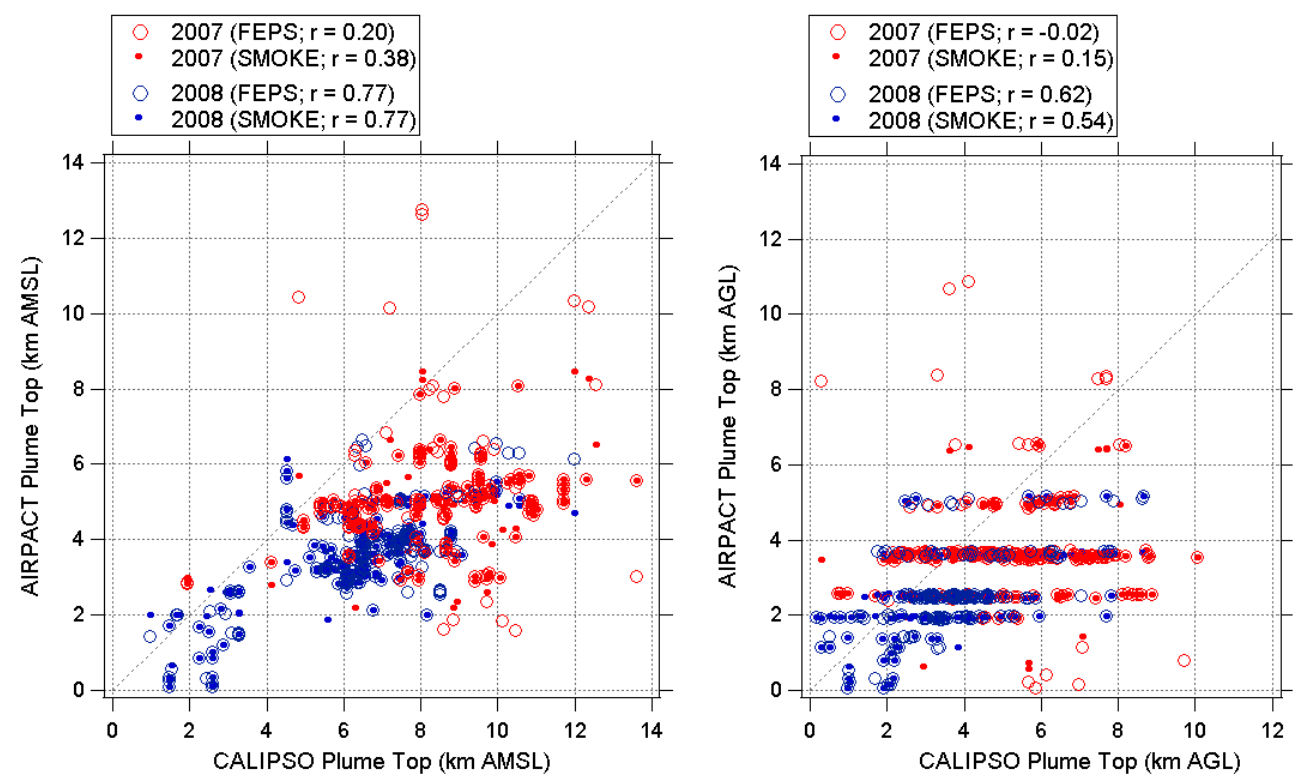

Figure 7. AIRPACT-3 vs. CALIOP plume top heights for 2007 (red) and 2008 (blue) when CALIPSO passed over the Idaho and California wildfires, respectively ( $\sim 2$ p.m. LST). Plume top heights above sea level (left) and above ground level (right) are shown for both the FEPS plume rise (open circle) and SMOKE plume-rise (solid dot) scenarios. Note that plume top heights are only shown for locations where both CALIOP and AIRPACT-3 showed an aerosol plume. 
Table 4. Summary of FEPS plume-rise scenario matched threshold comparison (SMOKE plume-rise scenario shown in parentheses when different) from 3 July to 23 August 2007 (top) and 22 June to 27 August 2008 (bottom). "Matched Threshold" refers to both model and observation values being removed from the analysis if either is below the threshold in combination with satellite statistics using rural sites only.

\begin{tabular}{|c|c|c|c|c|}
\hline Species & $\begin{array}{r}\mathrm{A} 24 \mathrm{~h} \\
\mathrm{PM}_{2.5} \\
\mu \mathrm{g} \mathrm{m}^{-3}\end{array}$ & AOD & $\begin{array}{r}\text { Tot. Col. CO } \\
\left(10^{18} \text { molec. } \mathrm{cm}^{-2}\right)\end{array}$ & $\begin{array}{r}\text { Trop. Col. NO } \\
\left(10^{15} \text { molec. } \mathrm{cm}^{-2}\right)\end{array}$ \\
\hline \multicolumn{5}{|l|}{3 July-22 August 2007} \\
\hline Source & EPA AQS & MODIS & AIRS & OMI \\
\hline Threshold & 10 & 0.3 & 1.9 & 1.0 \\
\hline Paired points & 555 & 150 & 356 & 599 \\
\hline Correlation $(r)$ & $0.4(0.5)$ & 0.0 & $0.3(0.4)$ & 0.2 \\
\hline Measured mean & 16.8 & 0.5 & 2.1 & 1.7 \\
\hline Mean bias & $5.9(-0.1)$ & -0.3 & $-0.3(-0.2)$ & -1.1 \\
\hline Mean error & $19.1(12.1)$ & 0.4 & 0.4 & 1.2 \\
\hline Normalized mean bias (\%) & $24(-3)$ & $-66(-47)$ & $-15(-8)$ & $-59(-60)$ \\
\hline Normalized mean error $(\%)$ & $104(70)$ & $77(84)$ & $17(19)$ & 68 \\
\hline Fractional bias $(\%)$ & $-38(-36)$ & $-117(-101)$ & $-18(-10)$ & $-97(-98)$ \\
\hline Fractional error $(\%)$ & $80(-10)$ & $123(115)$ & 19 & $101(102)$ \\
\hline \multicolumn{5}{|l|}{22 June-27 August 2008} \\
\hline Source & EPA AQS & MODIS & AIRS & OMI \\
\hline Threshold & 10 & 0.3 & 1.9 & 1.0 \\
\hline Paired points & 872 & 260 & 521 & 755 \\
\hline Correlation $(r)$ & 0.4 & $0.1(0.23$ & $0.3(0.2)$ & 0.3 \\
\hline Measured mean & 15.9 & 0.5 & 2.1 & 1.6 \\
\hline Mean bias & $-6.5(-5.6)$ & $-0.4(-0.3)$ & $-0.3(-0.2)$ & -0.9 \\
\hline Mean error & $9.0(8.4)$ & 0.4 & 0.3 & 1.1 \\
\hline Normalized mean bias (\%) & $-35(-33)$ & $-73(60)$ & $-11(-8)$ & $-54(-57)$ \\
\hline Normalized mean error \%) & $56(53)$ & $77(75)$ & 12 & 66 \\
\hline Fractional bias $(\%)$ & $-66(-57)$ & $-125(-105)$ & $-12(-9)$ & $-90(-93)$ \\
\hline Fractional error $(\%)$ & $77(71)$ & $128(113)$ & $14(13)$ & $95(97)$ \\
\hline
\end{tabular}

Table 5. Plume top height model comparisons with CALIOP for the FEPS plume-rise scenario (SMOKE plume-rise scenario shown in parentheses when different). Please note that some plumes contribute multiple paired points.

\begin{tabular}{lrrrr}
\hline Year & \multicolumn{2}{c}{2007} & \multicolumn{2}{c}{2008} \\
\hline Vertical reference & AGL & AMSL & AGL & AMSL \\
Paired points & $219(218)$ & $219(218)$ & $275(281)$ & $275(281)$ \\
Correlation $(r)$ & $0(0.2)$ & $0.2(0.4)$ & $0.6(0.5)$ & 0.8 \\
Measured mean $(\mathrm{km})$ & $5.2(5.1)$ & $8.2(8.0)$ & 3.5 & 5.6 \\
Mean bias $(\mathrm{km})$ & $-1.4(-1.5)$ & -3.1 & $-1.0(-0.9)$ & $-2.3(-2.2)$ \\
Mean error $(\mathrm{km})$ & $2.1(1.9)$ & $3.3(3.2)$ & $1.3(1.2)$ & $2.3(2.2)$ \\
Normalized mean bias $(\%)$ & $-3(-10)$ & $-34(-35)$ & $-16(-10)$ & $-39(-35)$ \\
Normalized mean error $(\%)$ & $52(45)$ & 38 & $43(42)$ & $40(36)$ \\
Fractional bias $(\%)$ & -28 & -46 & $-32(-26)$ & $-52(-46)$ \\
Fractional error $(\%)$ & $46(45)$ & $49(48)$ & $45(42)$ & $53(48)$ \\
\hline
\end{tabular}

data pairs that were in agreement, with values higher than the annual threshold, by $17 \%$ (2.1\% of the total data pairs). Further details of the $\mathrm{PM}_{2.5}$ NAAQS comparison are in Table 6 and Figs. S9-S10.

\subsection{Mt. Bachelor observatory comparison}

Hourly observed and predicted AIRPACT-3 values for PM, carbon monoxide, and ozone at Mt. Bachelor Observatory during the 2008 California wildfires (Fig. 9) show how AIRPACT-3 generally does with medium-range transport 
Table 6. $\mathrm{PM}_{2.5}$ National Ambient Air Quality Standards summary for both 2007 and 2008 fire periods analyzed per site per day for the FEPS plume-rise scenario (change due to SMOKE plume-rise scenario shown in parentheses).

\begin{tabular}{|c|c|c|c|c|c|c|}
\hline Year & Monitors & Days & $\begin{array}{r}\text { Matched } \\
\text { exceedances }\end{array}$ & $\begin{array}{l}\text { Predictions } \\
\text { unmatched }\end{array}$ & $\begin{array}{r}\text { Observations } \\
\text { unmatched }\end{array}$ & $\begin{array}{r}\text { No } \\
\text { exceedances }\end{array}$ \\
\hline \multicolumn{7}{|c|}{$24 \mathrm{~h}$ NAAQS threshold $\left(35 \mu \mathrm{g} \mathrm{m} \mathrm{m}^{3}\right)$} \\
\hline 2007 & 67 & 51 & 12 & $77(-21)$ & 10 & $3168(+21)$ \\
\hline \multirow[t]{3}{*}{2008} & 82 & 67 & $5(-1)$ & $74(-20)$ & $19(+1)$ & $5231(+20)$ \\
\hline & & Totals: & $17(-1)$ & $151(-41)$ & $29(+1)$ & $8399(+41)$ \\
\hline & & Percent: & $0.2 \%$ & $1.8 \%(-0.5 \%)$ & $0.3 \%$ & $97.7 \%(+0.5 \%)$ \\
\hline \multicolumn{7}{|c|}{ Annual NAAQS threshold $\left(12 \mu \mathrm{g} \mathrm{m}^{3}\right)$} \\
\hline 2007 & 67 & 51 & $157(+12)$ & $206(-25)$ & $242(-12)$ & $5929(+25)$ \\
\hline \multirow[t]{3}{*}{2008} & 82 & 67 & $146(+40)$ & $393(+34)$ & $454(-40)$ & $9665(-34)$ \\
\hline & & Totals & $303(+52)$ & $599(+9)$ & $696(-50)$ & $15594(-9)$ \\
\hline & & Percent: & $1.8 \%(+0.3 \%)$ & $3.5 \%$ & $4.0 \%(-0.3 \%)$ & $90.7 \%$ \\
\hline
\end{tabular}
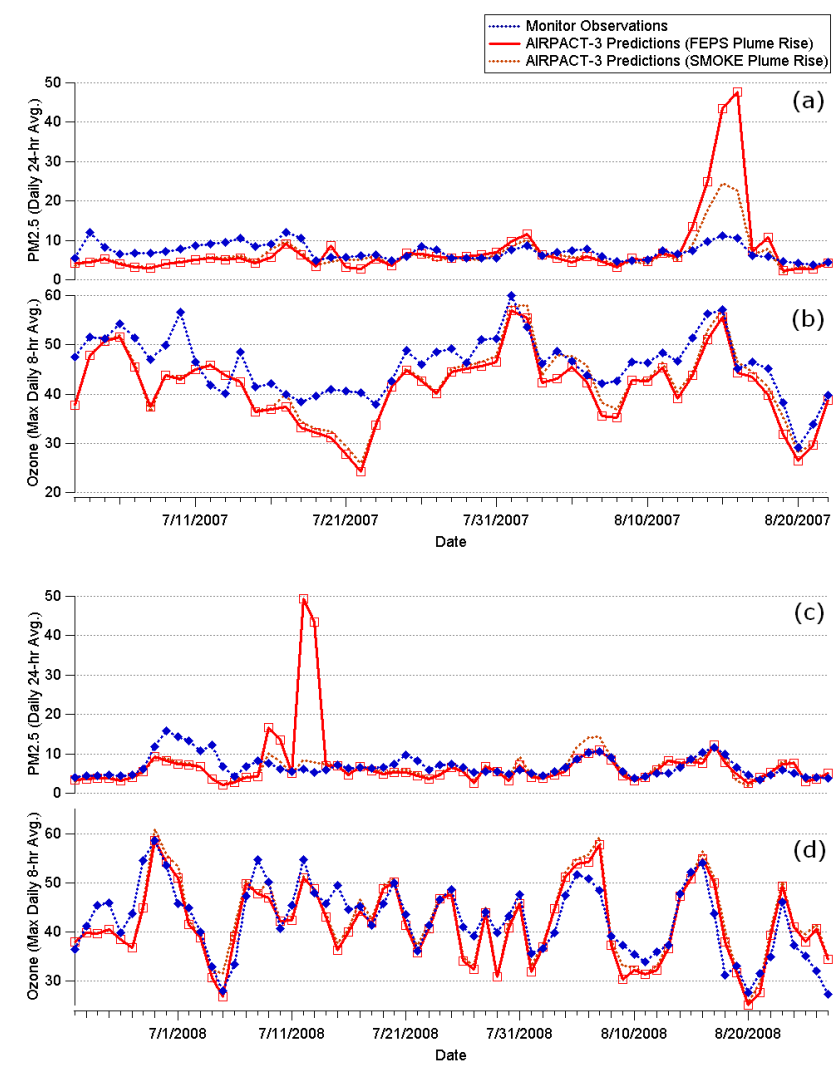

Figure 8. 3 July to 22 August 2007 (top) daily $24 \mathrm{~h}$ average $\mathrm{PM}_{2.5}$ averaged across 67 sites (a) and max daily $8 \mathrm{~h}$ average ozone averaged across 10 sites (b); 22 June to 27 August 2008 (bottom) daily $24 \mathrm{~h}$ average $\mathrm{PM}_{2.5}$ averaged across 82 sites (c) and max daily $8 \mathrm{~h}$ average ozone averaged across 18 sites (d) from. Model simulations are shown in red with squares (FEPS plume rise) and orange dotted (SMOKE plume rise) while observations are shown in dotted blue with diamonds. of wildfire emissions. There is evidence of model underprediction, especially in the FEPS plume-rise scenario, but the SMOKE plume-rise scenario resulted in over-prediction of $\mathrm{CO}$ for most fire events. There was generally good agreement of the timing of pollution events but occasionally the timing was off by a day, as occurred on 8-9 August (Fig. 9). Note that PM for AIRPACT-3 in the Mt. Bachelor analysis is reported as $\mathrm{PM}_{2.5}$ but the observations are of submicron aerosols converted from scattering observations using the method described in Wigder et al. (2013), which can have large uncertainty when there is significant variance in the aerosol size distribution (Akagi et al., 2012).

On 20 July 2008, there was a large transport event that carried pollutants northwest from the fires in California until reaching the coast of Oregon where the plume was diverted inland to the northeast, sweeping across Oregon (Figs. 6, S8, S11). MBO measurements of sub-micron PM were between 80 and $120 \mu \mathrm{g} \mathrm{m}^{-3}$ from midnight to noon, and between 20 and $45 \mu \mathrm{g} \mathrm{m}^{-3}$ for the proceeding $24 \mathrm{~h}$. AIRPACT3 predictions of carbon monoxide and $\mathrm{PM}_{2.5}$ were well timed with monitor observations, but the AIRPACT-3 FEPS plumerise scenario consistently under-predicted $\mathrm{CO}$ and PM concentrations during the event while the SMOKE plume-rise scenario did better on average but still under-predicted PM. The event did not have emissions from outside the domain that significantly contributed to the plume, but some model aerosols were clearly lost to the domain boundary. However, the aerosol transported out of the boundary was not enough to explain well-predicted carbon monoxide combined with $30-50 \%$ under-predictions in PM. There was a smaller event with similar comparisons between observations and predictions on 25 July 2008 as well. Throughout the 2008 MBO analysis dates, AIRPACT-3 generally under-predicted aerosols when $\mathrm{CO}$ was predicted well and over-predicted $\mathrm{CO}$ when aerosols were predicted well. This is consistent with other observations that show AIRPACT-3 $\mathrm{PM}_{2.5} / \mathrm{CO}$ ratios 


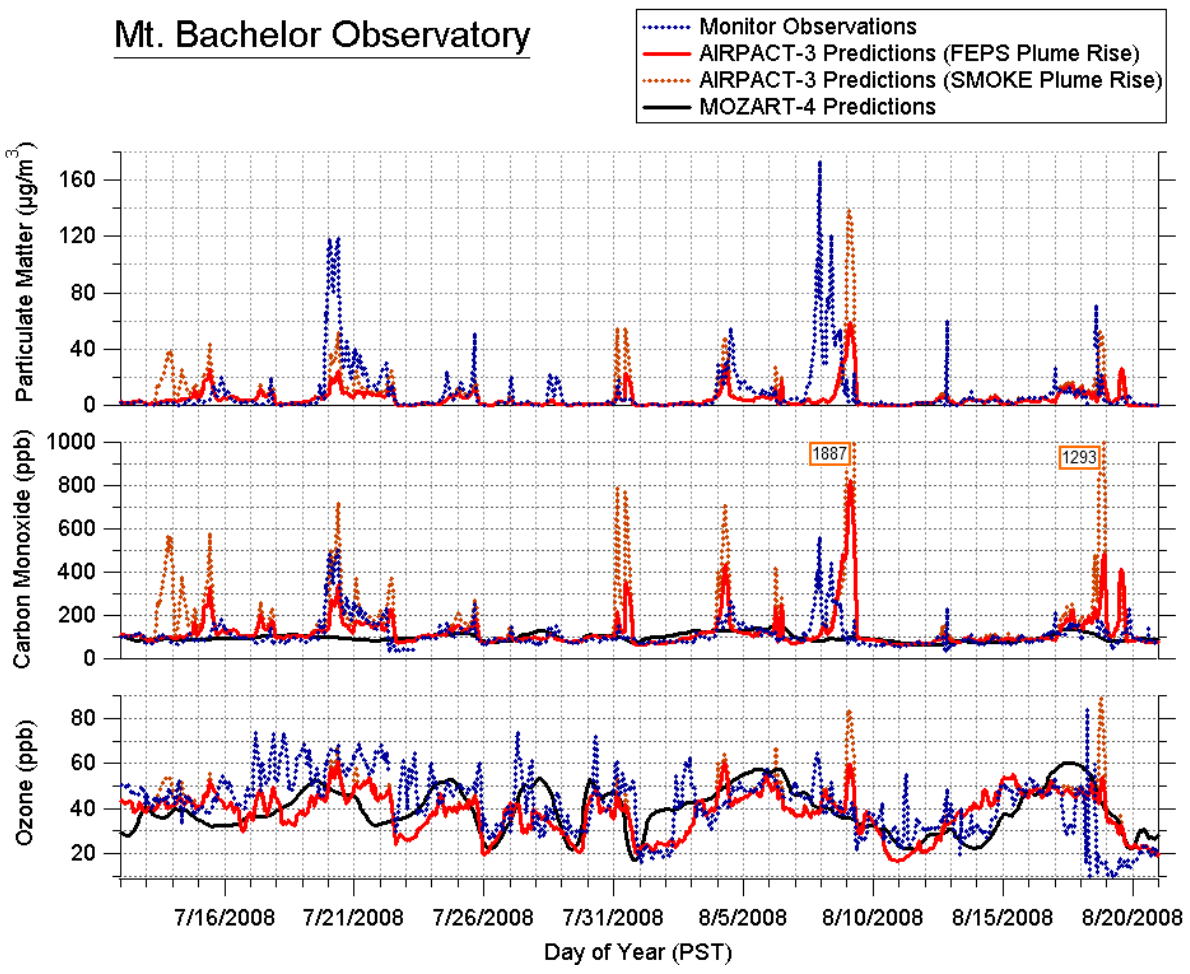

Figure 9. Particulate matter (top), carbon monoxide (middle), and ozone (bottom) at Mt. Bachelor Observatory for 12 July to 21 August 2008. AIRPACT-3 model simulations are shown in red (FEPS plume rise) and orange (SMOKE plume rise), MOZART-4 model simulations are shown in black, and observations are shown in dotted blue. Note that aerosols for AIRPACT-3 are reported as PM 2.5 and observed aerosols are sub-micron aerosols converted from scattering observations using the method described in Wigder et al. (2013).

to be low at locations greater than $\sim 100 \mathrm{~km}$ from the fire location. Observations on 20, 25 July, and 9 August resulted in PM1/CO ratios of $\sim 0.3 \mu \mathrm{g} \mathrm{m}^{-3} \mathrm{ppbv}^{-1}$, higher than the ratios observed for fires in closer proximity to $\mathrm{MBO}$, which has been previously interpreted to indicate secondary organic aerosol (SOA) formation during plume transport (Wigder et al., 2013).

The remote sensing comparison of the unique event on 20 July 2008 confirmed a consistent negative bias in predicted transported aerosols, even where CO in the SMOKE plume-rise scenario agreed well with AIRS. MODIS observed AOD values as high as 1.2 directly northwest of $\mathrm{MBO}$, with lower values near 0.4 directly over the site. AIRPACT- 3 only predicted AOD of 0.1 to 0.4 through the region of the large plume over those same regions around $\mathrm{MBO}$ (Fig. 6). AIRS also retrieved good quality carbon monoxide columns west of MBO, in the more concentrated part of the plume, showing a model under-bias of $\sim 10 \%$. Tropospheric $\mathrm{NO}_{2}$ columns over the transported portion of the plume were below the signal to noise threshold of OMI.

\section{Discussion}

AIRPACT-3 correctly predicted which regions were impacted by fires in Idaho, Montana, Nevada, California, and Oregon during the summers of 2007 and 2008. This is reflected in the comparisons to AIRS carbon monoxide, OMI tropospheric $\mathrm{NO}_{2}$, and MODIS AOD, which all exhibited good spatiotemporal correlation to AIRPACT-3. General model performance was quite similar between the 2 years, which suggests that the differences from using MM5 in 2007 and WRF in 2008 did not have a significant effect on the chemical transport modeling during the fire events.

The SMOKE plume-rise scenario exhibited the best comparisons, with average fractional biases at $\sim 2 \mathrm{p} . \mathrm{m}$. for AOD, tropospheric column $\mathrm{NO}_{2}$ and total column $\mathrm{CO}$ found to be $-61 \%,-39 \%$, and $-10 \%$ during the 2007 fire period, respectively; while during the 2008 fire period the average fractional biases were $-53 \%,-28 \%$, and $-5 \%$ respectively. Surface concentrations of $\mathrm{PM}_{2.5}$ were also reasonable, especially in the SMOKE plume-rise scenarios, which lifted some of the surface emissions aloft and constrained large plume top heights. The fractional bias of daily average $24 \mathrm{~h}$ $\mathrm{PM}_{2.5}$ was found to be approximately $-30 \%$ during both fire periods. Fractional biases of AIRPACT-3 plume tops were found to be $-46 \%$ above mean sea level, but only $-28 \%$ 
above ground level, partly due to the under-estimation of AIRPACT-3 elevation in complex terrain. Underestimation of plume heights, which affects transport, may be partly responsible for under-prediction in transported aerosols. However, the under-prediction of SOA in model simulations is likely the largest source of model error, especially when we consider that other factors, such as $\mathrm{CO}$, were not underpredicted by such large magnitudes.

Fire emissions generated from south of the domain were not well represented in AIRPACT-3 chemical boundary conditions derived from MOZART-4; a few events in 2008 appeared to be significantly affected by those under-predictions in boundary condition concentrations. This is consistent with the analysis of Pfister et al. (2011) that showed FINN emission factors were too low in the 2008 California fire simulations due to a misclassification of fuel type. MOZART-4 showed general agreement with the background values of $\mathrm{CO}$ and $\mathrm{O}_{3}$ (Fig. 9), but missed the high values expected from fires due to the coarse model resolution and the underestimation of fire emissions and plume height. Thus AIRPACT-3 model performance would benefit from revised methods to better represent fire influence on AIRPACT-3 boundary conditions.

Comparisons of AIRPACT-3 plumes with CALIOP show that the dynamics of plume dispersion in the model are greatly affected by errors in surface terrain and vertical plume distribution, and their interaction with the wind profiles. There is also evidence that the underestimation of terrain height in AIRPACT-3 and the overestimation of plumetop heights AGL could be compensating for errors in some of the FEPS plume-rise scenarios.

AIRPACT-3 tropospheric $\mathrm{NO}_{2}$ was generally underpredicted, but there were occasionally what appeared to be large overestimates of tropospheric $\mathrm{NO}_{2}$ in regions near active fires (Figs. S5a, S5b, S7a, S7b). It is important to note that these large tropospheric $\mathrm{NO}_{2}$ predictions shown are a direct result of our application of the OMI averaging kernel, which weights the upper troposphere with a factor greater than one. In most cases, the plumes are low enough to the ground that the averaging kernel causes a net reduction in AIRPACT-3 tropospheric $\mathrm{NO}_{2}$ columns. However, in cases where FEPS considerably over-predicted plume top height, the modeled tropospheric $\mathrm{NO}_{2}$ column convolved with the averaging kernel caused a spike much higher than that of the original AIRPACT-3 results. The effect still occurs in the SMOKE plume-rise scenario, though there are fewer extreme instances. Furthermore, the OMI tropospheric $\mathrm{NO}_{2}$ algorithms have large errors over wildfires due to a combination of the a priori profiles used that assume $\mathrm{NO}_{2}$ is concentrated near the surface, the high aerosol loadings emitted, and issues with comparisons over complex terrain (Boersma et al., 2011).

Collectively, the results of this analysis show that AIRPACT-3 can over-predict surface fire emissions and occasionally under-predict fire emissions aloft which, cou- pled with discrepancies in modeled surface elevation, significantly affects the ability of AIRPACT- 3 to accurately predict downwind surface concentrations of transported pollutants in complex terrain. Our analysis shows that AIRPACT-3 CO performs quite well when compared to surface concentrations (Fig. 9) and AIRS total column retrievals (Figs. 5, $6, \mathrm{~S} 5 \mathrm{a}, \mathrm{S} 5 \mathrm{~b})$. This is in contrast to the frequent underestimates of transported aerosols that were evident in AIRPACT3 predictions of surface $\mathrm{PM}_{2.5}$ (Fig. 9) and AOD (Figs. 4, 5, 6 , S5a). Satellite comparisons clearly show that when modeled $\mathrm{CO}$ across the domain is largely in close agreement with observations, aerosol performance systematically degrades with distance from the fire source. Akagi et al. (2011) and Yokelson et al. (2013) suggest that the emission factors for volatile organic compounds (VOCs) used in CONSUME-3 (Hardy, 1996 and Ward et al., 1989) should be much higher. This underestimation in VOC emissions further exacerbates known under-predictions of SOA in CMAQ, which can be a significant fraction of the total $\mathrm{PM}_{2.5}$ for plumes transported large distances (Wigder et al., 2013; Strand et al., 2012; Hu et al., 2008; Heilman et al., 2013) and is highly variable (Jolleys et al., 2012; Yokelson et al., 2009; Vakkari et al., 2014).

\section{Conclusions and future work}

In general, AIRPACT-3 over-predicts pollutant concentrations due to near-source surface emissions from fires and under-predicts concentrations associated with long-range transport, both from within the domain and outside the domain. Most fire locations are captured by the BlueSky SMARTFIRE tool, but there are occasionally fires predicted that are poorly timed or are missed. Our analysis suggests that total fire emissions in the domain are, overall, modestly under-predicted. Although we have shown that AIRPACT3 chemical boundary conditions largely underestimate fireemissions from outside the domain, this problem does not explain most under-predictions that occur at ground sites. The under-predictions are instead likely due to a combination of some or all of the following: (1) underestimates of area burned in the SMARTFIRE feed; (2) underestimates of fuel mass, especially in shrub-lands and other vegetation types that have sparse woody fuels but are classified with zero dead woody fuels in the FCCS; (3) underestimates of VOC emissions in the Consume model; (4) under-predictions of SOA production in CMAQ, thus causing under-predictions of PM in plumes that travel large distances; and (5) terrain height in the AIRPACT-3 model is too smooth in mountainous areas, causing problems with the elevation of emissions and dynamics of transport. Under-predictions in fire size also scale directly with under-predictions in plume top heights, since heat content of a fire is directly proportional to the total fuel in Consume, which adds uncertainty to predictions of transport. 
The high-resolution MODIS AOD retrievals provided considerable insight into AIRPACT aerosol performance. We also feel that alternative retrieval algorithms better suited for fire plume conditions might address some of the errors associated with AIRS and OMI trace gas comparisons. Furthermore, we recognize that coupling fire dynamics with meteorological simulations, such as in the WRF-Fire framework (Coen et al., 2013; Kochanski et al., 2013; Mandel et al., 2011) may be the best method for forecasts once WRF-Fire simulations can be generated fast enough. We have recently updated the system to AIRPACT-4, which includes $4 \mathrm{~km} \times 4 \mathrm{~km}$ horizontal grid cells and the SMOKE plume-rise method, in addition to the updated BlueSky software, which includes higher resolution fuel loading in FCCS and an updated SMARTFIRE (v2). Canadian fires within the model domain will be included, starting in 2015, but AIRPACT-4 would still benefit by having chemical boundary conditions that accurately represent smoke originating from outside the AIRPACT domain. Planned updates to the AIRPACT vertical layer spacing in the middle troposphere should also help model performance during fire emissions transport events.

\section{The Supplement related to this article is available online at doi:10.5194/acp-14-12533-2014-supplement.}

Acknowledgements. This research was made possible by a NASA grant (NNX11AE57G) and was also partially supported by a grant from the National Science Foundation's REU program (0754990). The National Center for Atmospheric Research is funded by the National Science Foundation and operated by the University Corporation for Atmospheric Research. The Mt. Bachelor Observatory is supported by the National Science Foundation (AGS-1066032AM002). NW-AIRQUEST provides support for the operation of the AIRPACT forecast system. We would also like to thank Matthew Mavko and other affiliates of the Western Regional Air Partnership. The work was also partially supported by NSF award AGS1032165 and the Joint Fire Science Program award 11-1-5-13.

Edited by: S. Brown

\section{References}

Akagi, S. K., Yokelson, R. J., Wiedinmyer, C., Alvarado, M. J., Reid, J. S., Karl, T., Crounse, J. D., and Wennberg, P. O.: Emission factors for open and domestic biomass burning for use in atmospheric models, Atmos. Chem. Phys., 11, 4039-4072, doi:10.5194/acp-11-4039-2011, 2011.

Akagi, S. K., Craven, J. S., Taylor, J. W., McMeeking, G. R., Yokelson, R. J., Alvarado, M. J., Logan, J. A., Mao, J., Apel, E., Riemer, D., Blake, D., Cohen, R. C., Min, K.-E., Perring, A. E., Browne, E. C., Wooldridge, P. J., Diskin, G. S., Sachse, G.
W., Fuelberg, H., Sessions, W. R., Harrigan, D. L., Huey, G., Liao, J., Case-Hanks, A., Jimenez, J. L., Cubison, M. J., Vay, S. A., Weinheimer, A. J., Knapp, D. J., Montzka, D. D., Flocke, F. M., Pollack, I. B., Wennberg, P. O., Kurten, A., Crounse, J., Clair, J. M. St., Wisthaler, A., Mikoviny, T., Yantosca, R. M., Carouge, C. C., and Le Sager, P.: Nitrogen oxides and PAN in plumes from boreal fires during ARCTAS-B and their impact on ozone: an integrated analysis of aircraft and satellite observations, Atmos. Chem. Phys., 10, 9739-9760, doi:10.5194/acp10-9739-2010, 2010.

Alvarado, M. J., Logan, J. A., Mao, J., Apel, E., Riemer, D., Blake, D., Cohen, R. C., Min, K.-E., Perring, A. E., Browne, E. C., Wooldridge, P. J., Diskin, G. S., Sachse, G. W., Fuelberg, H., Sessions, W. R., Harrigan, D. L., Huey, G., Liao, J., Case-Hanks, A., Jimenez, J. L., Cubison, M. J., Vay, S. A., Weinheimer, A. J., Knapp, D. J., Montzka, D. D., Flocke, F. M., Pollack, I. B., Wennberg, P. O., Kurten, A., Crounse, J., Clair, J. M. St., Wisthaler, A., Mikoviny, T., Yantosca, R. M., Carouge, C. C., and Le Sager, P.: Nitrogen oxides and PAN in plumes from boreal fires during ARCTAS-B and their impact on ozone: an integrated analysis of aircraft and satellite observations, Atmos. Chem. Phys., 10, 9739-9760, doi:10.5194/acp-10-9739-2010, 2010.

Ambrose, J. L., Reidmiller, D. R., and Jaffe, D. A.: Causes of high $\mathrm{O}_{3}$ in the lower free troposphere over the Pacific Northwest as observed at the Mt. Bachelor Observatory, Atmos. Environ., 45, 5302-5315, doi:10.1016/j.atmosenv.2011.06.056, 2011.

Anderson, G. K., Sandberg, D. V., and Norheim, R. A.: Fire Emission Production Simulator (FEPS) User's Guide, Joint Fire Science Program and the National Fire Plan, January, USDA Forest Service available at: http://www.fs.fed.us/pnw/fera/feps/FEPS_ users_guide.pdf, 2004.

Bhoi, S., Qu, J. J., Dasgupta, S.: Multi-sensor study of aerosols from 2007 Okefenokee forest fire, J. Appl. Remote Sens., 3, 031501, doi:10.1117/1.3078070, 2009.

Binkowski, F. S. and Roselle, S. J.: Models-3 Community Multiscale Air Quality (CMAQ) model aerosol component, 1. Model description, J. Geophys. Res., 108, 4183, doi:10.1029/2001JD001409,2003.

Boersma, K. F., Eskes, H. J., Veefkind, J. P., Brinksma, E. J., van der A, R. J., Sneep, M., van den Oord, G. H. J., Levelt, P. F., Stammes, P., Gleason, J. F., and Bucsela, E. J.: Near-real time retrieval of tropospheric $\mathrm{NO}_{2}$ from OMI, Atmos. Chem. Phys., 7, 2103-2118, doi:10.5194/acp-7-2103-2007, 2007.

Boersma, K. F., Eskes, H. J., Dirksen, R. J., van der A, R. J., Veefkind, J. P., Stammes, P., Huijnen, V., Kleipool, Q. L., Sneep, M., Claas, J., Leitão, J., Richter, A., Zhou, Y., and Brunner, D.: An improved tropospheric $\mathrm{NO}_{2}$ column retrieval algorithm for the Ozone Monitoring Instrument, Atmos. Meas. Tech., 4, 1905-1928, doi:10.5194/amt-4-1905-2011, 2011.

Burling, I. R., Urbanski, S. P., Wold, C. E., Seinfeld, J. H., Coe, H., Alvarado, M. J., and Weise, D. R.: Evolution of trace gases and particles emitted by a chaparral fire in California, Atmos. Chem. Phys., 12, 1397-1421, doi:10.5194/acp-12-1397-2012, 2012.

Byun, D. and Schere, K. L.: Review of the governing equations, computational algorithms, and other components of the models3 Community Multiscale Air Quality (CMAQ) modeling system, Appl. Mech. Rev., 59, 51-77, doi:10.1115/1.2128636, 2006.

Calipso User Guide: CALIPSO Lidar Level-2 $5 \mathrm{~km}$ Vertical Feature Mask (VFM) Products, NASA Langley Research 
Center, available at: http://www-calipso.larc.nasa.gov/resources/ calipso_users_guide/data_summaries/vfm/ (last access: 6 October 2011), 2011.

Chen, J., Vaughan, J., Avise, J., O’Neill, S., and Lamb, B.: Enhancement and evaluation of the AIRPACT ozone and $\mathrm{PM}_{2.5}$ forecast system for the Pacific Northwest, J. Geophys. Res., 113, D14305, doi:10.1029/2007JD009554, 2008.

Christopher, S., Gupta, P., Nair, U., Jones, T. A., Kondragunta, S., Wu, Y.-L., Hand, J., and Zhang, X.: Satellite remote sensing and mesoscale modeling of the 2007 Georgia/Florida fires, IEEE J. Sel. Top. Appl., JSTARS-2009-00020, 26, 1-13, 2009.

Coen, J., Cameron, M., Michalakes, J., Patton, E., Riggan, P., and Yedinak, K.: WRF-Fire: coupled weather-wildland fire modeling with the weather research and forecasting model, J. Appl. Meteorol. Clim., 52, 16-38, doi:10.1175/JAMC-D-12-023.1, 2013.

Deeter, M. N., Edwards, D. P., Gille, J. C., Emmons, L. K., Francis, G., Ho, S. P., Mao, D., Masters, D., Worden, H., Drummond, J. R., and Novelli, P. C.: The MOPITT version 4 CO product: algorithm enhancements, validation, and long-term stability, J. Geophys. Res., 115, D07306, doi:10.1029/2009JD013005, 2010.

Drury, E., Jacob, D. J., Wang, J., Spurr, R. J. D., and Chance, K.: Improved algorithm for MODIS satellite retrievals of aerosol optical depths over western North America, J. Geophys. Res., 113, D16204, doi:10.1029/2007JD009573, 2008.

Eck, T. F., Holben, B. N., Reid, J. S., Mukelabai, M. M., Piketh, S. J., Torres, O., Jethva, H. T., Hyer, E. J., Ward, D. E., Dubovik, O., Sinyuk, A., Schafer, J.S., Giles, D. M., Sorokin, M., Smirnov, A., and Slutsker, I.: A seasonal trend of single scattering albedo in southern African biomass-burning particles: Implications for satellite products and estimates of emissions for the world's largest biomass-burning source, J. Geophys. Res. Atmos., 118, 6414-6432, doi:10.1002/jgrd.50500, 2013.

Emmons, L. K., Walters, S., Hess, P. G., Lamarque, J.-F., Pfister, G. G., Fillmore, D., Granier, C., Guenther, A., Kinnison, D., Laepple, T., Orlando, J., Tie, X., Tyndall, G., Wiedinmyer, C., Baughcum, S. L., and Kloster, S.: Description and evaluation of the Model for Ozone and Related chemical Tracers, version 4 (MOZART-4), Geosci. Model Dev., 3, 43-67, doi:10.5194/gmd3-43-2010, 2010.

Engel-Cox, J. A., Holloman, C. H., Coutant, B. W., Hoff, R. M.: Qualitative and quantitative evaluation of MODIS satellite sensor data for regional and urban scale air quality, Atmos. Environ., 38, 2495-2509, doi:10.1016/j.atmosenv.2004.01.039, 2004.

Evans, T. N. and Fournier, G. R.: Simple approximation to extinction efficiency valid over all size range, Appl. Optics, 29, 46664670, 1990.

Green, M., Kondragunta, S., Ciren, P., Xu, C.: Comparison of GOES and MODIS Aerosol Optical Depth (AOD) to AErosol RObotic NETwork (AERONET) AOD and IMPROVE PM 2.5 mass at Bondville, Illinois, J. Air Waste Manage., 59, 10821091, doi:10.3155/1047-3289.59.9.1082, 2009.

Hardy, C.: Guidelines for Estimating Volume, Biomass, and Smoke Production for Piled Slash. Gen. Tech. Rep PNW-GTR-364. Portland, OR: U.S. Department of Agriculture, Forest Service, Pacific Northwest Research Station, 1996.

Heilman, W. E., Liu, Y., Urbanski, S., Kovalev, V., and Mickler, R.: Wildland fire emissions, carbon, and climate: Plume rise, atmospheric transport, and chemistry processes, Forest Ecol. Manage., doi:10.1016/j.foreco.2013.02.001, 2013.
Herron-Thorpe, F. L., Lamb, B. K., Mount, G. H., and Vaughan, J. K.: Evaluation of a regional air quality forecast model for tropospheric $\mathrm{NO}_{2}$ columns using the OMI/Aura satellite tropospheric $\mathrm{NO}_{2}$ product, Atmos. Chem. Phys., 10, 88398854, doi:10.5194/acp-10-8839-2010, 2010.

Herron-Thorpe, F. L., Mount, G. H., Emmons, L. K., Lamb, B. K., Chung, S. H., and Vaughan, J. K.: Regional air-quality forecasting for the Pacific Northwest using MOPITT/TERRA assimilated carbon monoxide MOZART-4 forecasts as a near realtime boundary condition, Atmos. Chem. Phys., 12, 5603-5615, doi:10.5194/acp-12-5603-2012, 2012.

Hoff, R. M. and Christopher, S. A.: Remote sensing of particulate pollution from space: Have we reached the promised land?, J. Air Waste Manage., 59, 645-675, 2009.

Hu, Y., Talat Odman, M., Chang, M. E., Jackson, W., Lee, S., Edgerton, E. S., Baumann, K., and Russell, A. G.: Simulation of air quality impacts from prescribed fires on an urban area, Environ. Sci. Technol., 42, 3676-3682, 2008.

Jolleys, M. D., Coe, H., McFiggans, G., Capes, G., Allan, J. D., Crosier, J., Williams, P. I., Allen, G., Bower, K. N., Jimenez, J. L., Russell, L. M., Grutter, M., and Baumgardner, D.: Characterizing the aging of biomass burning organic aerosol by use of mixing ratios: a meta-analysis of four regions, Environ. Sci. Technol., 46, 13093-13102, 2012.

Kahn, R. A.: Wildfire smoke injection heights: two perspectives from space, Geophys. Res. Lett., 35, L04809, doi:10.1029/2007GL032165, 2008.

Kahn, R. A., Gaitley, B. J., Garay, M. J., Diner, D. J., Eck, T., Smirnov, A., and Holben, B. N.: Multiangle imaging Spectroradiometer global aerosol product assessment by comparison with the aerosol robotic network, J. Geophys. Res. 115, D23209, doi:10.1029/2010JD014601, 2010.

Kochanski, A. K., Jenkins, M. A., Krueger, S. K., Mandel, J., and Beezley, J. D.: Real time simulation of 2007 Santa Ana fires, Forest Ecol. Manag., 15, 136-149, doi:10.1016/j.foreco.2012.12.014arXiv:1202.3209, 2013.

Larkin, N. K., O’Neill, S. M., Solomon, R., Raffuse, S., Strand, T., Sullivan, D. C., Krull, C., Rorig, M., Peterson, J., and Ferguson, S. A.: The BlueSky smoke modeling framework, Int. J. Wildland Fire, 18, 906-920, 2009.

Levy, R. C., Remer, L. A., Mattoo, S., Vermote, E. F., and Kaufman, Y. J.: Second-generation operational algorithm: retrieval of aerosol properties over land from inversion of moderate resolution imaging spectroradiometer spectral reflectance, J. Geophys. Res., 112, D13211, doi:10.1029/2006JD007811, 2007.

Maddy, E. S. and Barnet, C. D.: Vertical resolution estimates in version 5 of AIRS operational retrievals, IEEE T. Geosci. Remote, 46, 2375-2384, doi:10.1109/TGRS.2008.917498, 2008.

Mandel, J., Beezley, J. D., and Kochanski, A. K.: Coupled atmosphere-wildland fire modeling with WRF 3.3 and SFIRE 2011, Geosci. Model Dev., 4, 591-610, doi:10.5194/gmd-4-5912011, 2011.

Mass, C. F., Albright, M., Ovens, D., Steed, R., MacIver, M., Grimit, E., Eckel, T., Lamb, B., Vaughan, J., Westrick, K., Storck, P., Colman, B., Hill, C., Maykut, N., Gilroy, M., Ferguson, S. A., Yetter, J., Sierchio, J. M., Bowman, C., Stender, R., Wilson, R., and Brown, W.: Regional environmental prediction over the Pacific Northwest, B. Am. Meteorol. Soc., 84, 13531366, 2003. 
Mielonen, T., Arola, A., Komppula, M., Kukkonen, J., Koskinen, J., de Leeuw, G., and Lehtinen, K. E. J.: Comparison of CALIOP level 2 aerosol subtypes to aerosol types derived from AERONET inversion data, Geophys. Res. Lett., 36, L18804, doi:10.1029/2009GL039609, 2009.

Olsen, E. T., Fishbein, E., Lee, S. Y., Manning, E., Maddy, E., and McMillan, W. W.: AIRS/AMSU/HSB Version 5 Level 2 Product Levels, Layers and Trapezoids, Retrieval Channel Sets, Jet Propulsion Laboratory, California Institute of Technology, Pasadena, CA, 2007.

Omar, A. H., Winker, D. M., Kittaka, C., Vaughan, M. A., Liu, Z. Y., Hu, Y. X., Trepte, C. R., Rogers, R. R., Ferrare, R. A., Lee, K. P., Kuehn, R. E., and Hostetler, C. A.: The CALIPSO automated aerosol classification and lidar ratio selection algorithm, J. Atmos. Ocean. Technol., 26, 1994-2014, doi:10.1175/2009JTECHA1231.1, 2009.

Ottmar, R., Miranda, A., and Sandberg, D.: Characterizing sources of emissions from wildland fires, in: Wildland fires and air pollution, edited by: Bytnerowicz, A., Arbaugh, M., Riebau, A., Andersen, C., Amsterdam, Elsevier, 61-78. Chapter 3. (Developments in Environmental Science Series Volume 8), 2009.

Pfister, G. G., Avise, J., Wiedinmyer, C., Edwards, D. P., Emmons, L. K., Diskin, G. D., Podolske, J., and Wisthaler, A.: CO source contribution analysis for California during ARCTAS-CARB, Atmos. Chem. Phys., 11, 7515-7532, doi:10.5194/acp-11-75152011, 2011.

Pouliot, G., Pierce, T., Benjey, W., O’Neill, S. M., Ferguson, S. A.: Wildfire emission modeling: integrating BlueSky and SMOKE, in: Presentation at the 14th International Emission Inventory Conference, Transforming Emission Inventories Meeting Future Challenges Today, 11 April-14 April 2005, Las Vegas, NV, Session 12, available at: http://www.epa.gov/ttn/chief/conference/ ei14/session12/pouliot.pdf, 2005.

Raffuse, S. M., Pryden, D. A., Sullivan, D. C., Larkin, N. K., Strand, T., and Solomon., R.: SMARTFIRE algorithm description, report, Sonoma Technol. Inc., Petaluma, Calif., 2009.

Remer, L. A., Kaufman, Y. J., Tanre, D., Mattoo, S., Chu, D. A., Martins, J. V., Li, R. R., Ichoku, C., Levy, R. C., Kleidman, R. G., Eck, T. F., Vermote, E., and Holben, B. N.: The modis aerosol algorithm, products, and validation, J. Atmos. Sci., 62, 947-973, doi:10.1175/JAS3385.1, 2005.

Riccardi, C. L., Prichard, S. J., Sandberg, D. V., and Ottmar, R. D.: Quantifying physical characteristics of wildland fuels using the fuel characteristic classification system, Can. J. Forest Res., 37, 2413-2420, 2007.

Simon, H. and Bhave, P. V.: Simulating the degree of oxidation in atmospheric organic particles, Environ. Sci. Technol., 46, 331$339,2012$.

Skamarock, W. C., Klemp, J. B., Dudhia, J., Gill, D. O., Barker, D. M., Wang, W., and Powers, J. G.: A Description of the Advanced Research WRF Version 2, National Center for Atmosphreric Research, Boulder, Colorado, 2005.

Strand, T., Larkin, N. K., Rorig, M., Krull, C., Moore, M.: $\mathrm{PM}_{2.5}$ measurements in wildfire smoke plumes from fire seasons 20052008 in the Northwestern United States, J. Aerosol Sci., 42, 3, 143-155, 2011.

Strand, T. M., Larkin, N., Solomon, R., Rorig, N., Craig, K. J., Raffuse, S., Sullivan, D., Wheeler, N., and Pryden, D.: Analyses of BlueSky Gateway $\mathrm{PM}_{2.5}$ predictions during the 2007 south- ern and 2008 northern California fires, J. Geophys. Res., 117, D17301, doi:10.1029/2012JD017627, 2012.

Vakkari, V., Kerminen, V.-M., Beukes, J. P., Tiitta, P., van Zyl, P. G., Josipovic, M., Venter, A., Jaars, K., Worsnop, D., Kulmala, M., and Laakso, L.: Rapid changes in biomass burning aerosols by atmospheric oxidation, Geophys. Res. Lett., 41, doi:10.1002/2014GL059396, 2014.

Ward, D. E., Hardy, C. C., Sandberg, D. V., and Reinhardt, T. E.: Emissions characterization, in: Mitigation of prescribed fire atmospheric pollution through increased utilization of hardwoods, piled residues, and long-needled conifers, July 15, 1989, Final report to the Bonneville Power and US Department of Energy, Under IAG DEAI179-85BP18509 (PNW-85-423), 1989.

Weiss-Penzias, P., Jaffe, D. A., Swartzendruber, P., Dennison, J. B., Chand, D., Hafner, W., and Prestbo, E.: Observations of Asian air pollution in the free troposphere at Mt. Bachelor Observatory in the spring of 2004, J. Geophys. Res., 110, D10304, doi:10.1029/2005JD006522, 2006.

Wespes, C., Emmons, L., Edwards, D. P., Hannigan, J., Hurtmans, D., Saunois, M., Coheur, P.-F., Clerbaux, C., Coffey, M. T., Batchelor, R. L., Lindenmaier, R., Strong, K., Weinheimer, A. J., Nowak, J. B., Ryerson, T. B., Crounse, J. D., and Wennberg, P. O.: Analysis of ozone and nitric acid in spring and summer Arctic pollution using aircraft, ground-based, satellite observations and MOZART-4 model: source attribution and partitioning, Atmos. Chem. Phys., 12, 237-259, doi:10.5194/acp12-237-2012, 2012.

Wiedinmyer, C., Akagi, S. K., Yokelson, R. J., Emmons, L. K., AlSaadi, J. A., Orlando, J. J., and Soja, A. J.: The Fire INventory from NCAR (FINN): a high resolution global model to estimate the emissions from open burning, Geosci. Model Dev., 4, 625641, doi:10.5194/gmd-4-625-2011, 2011.

Wigder, N. L., Jaffe, D. A., Saketa, F. A.: Ozone and Particulate Matter Enhancements from Regional Wildfires Observed at Mount Bachelor during 2004-2011, Atmos. Environ., 75, 24-31, doi:10.1016/j.atmosenv.2013.04.026, 2013.

Winker, D. M., Vaughan, M. A., Omar, A., Hu, Y., Powell, K. A., Liu, Z., Hunt, W. H., and Young, S. A.: Overview of the CALIPSO mission and CALIOP data processing algorithms, J. Atmos. Ocean. Technol., 26, 2310-2323, doi:10.1175/2009JTECHA1281.1, 2009.

Yokelson, R. J., Crounse, J. D., DeCarlo, P. F., Karl, T., Urbanski, S., Atlas, E., Campos, T., Shinozuka, Y., Kapustin, V., Clarke, A. D., Weinheimer, A., Knapp, D. J., Montzka, D. D., Holloway, J., Weibring, P., Flocke, F., Zheng, W., Toohey, D., Wennberg, P. O., Wiedinmyer, C., Mauldin, L., Fried, A., Richter, D., Walega, J., Jimenez, J. L., Adachi, K., Buseck, P. R., Hall, S. R., and Shetter, R.: Emissions from biomass burning in the Yucatan, Atmos. Chem. Phys., 9, 5785-5812, doi:10.5194/acp-9-5785-2009, 2009.

Yokelson, R. J., Burling, I. R., Gilman, J. B., Warneke, C., Stockwell, C. E., de Gouw, J., Akagi, S. K., Urbanski, S. P., Veres, P., Roberts, J. M., Kuster, W. C., Reardon, J., Griffith, D. W. T., Johnson, T. J., Hosseini, S., Miller, J. W., Cocker III, D. R., Jung, H., and Weise, D. R.: Coupling field and laboratory measurements to estimate the emission factors of identified and unidentified trace gases for prescribed fires, Atmos. Chem. Phys., 13, 89-116, doi:10.5194/acp-13-89-2013, 2013. 